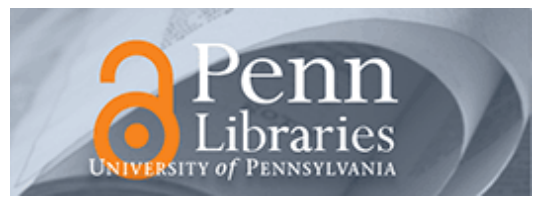

University of Pennsylvania

ScholarlyCommons

Operations, Information and Decisions Papers

Wharton Faculty Research

2002

\title{
Information Technology, Workplace Organization, and the Demand for Skilled Labor: Firm-Level Evidence
}

Timothy F. Bresnahan

Erik Brynjolfsson

Lorin M. Hitt

University of Pennsylvania

Follow this and additional works at: https://repository.upenn.edu/oid_papers

Part of the Business Administration, Management, and Operations Commons, Labor Economics Commons, Other Business Commons, and the Technology and Innovation Commons

\section{Recommended Citation}

Bresnahan, T. F., Brynjolfsson, E., \& Hitt, L. M. (2002). Information Technology, Workplace Organization, and the Demand for Skilled Labor: Firm-Level Evidence. The quarterly journal of economics, 117 (1), 339-376. http://dx.doi.org/10.1162/003355302753399526

This paper is posted at ScholarlyCommons. https://repository.upenn.edu/oid_papers/108

For more information, please contact repository@pobox.upenn.edu. 


\title{
Information Technology, Workplace Organization, and the Demand for Skilled Labor: Firm-Level Evidence
}

\author{
Abstract \\ We investigate the hypothesis that the combination of three related innovations -1 ) information \\ technology (IT), 2) complementary workplace reorganization, and 3) new products and \\ services-constitute a significant skill-biased technical change affecting labor demand in the United \\ States. Using detailed firm-level data, we find evidence of complementarities among all three of these \\ innovations in factor demand and productivity regressions. In addition, firms that adopt these innovations \\ tend to use more skilled labor. The effects of IT on labor demand are greater when IT is combined with \\ the particular organizational investments we identify, highlighting the importance of IT-enabled \\ organizational change.

\section{Disciplines} \\ Business Administration, Management, and Operations | Economics | Labor Economics | Other Business | \\ Technology and Innovation
}




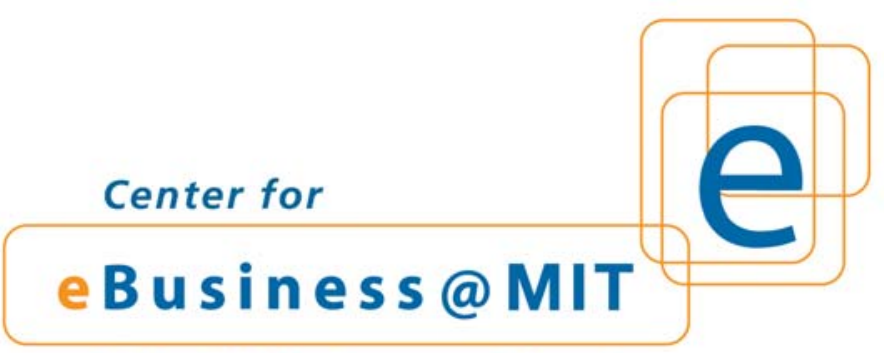

http://ebusiness.mit.edu

\section{Information Technology, Workplace Organization, and the Demand for Skilled Labor: Firm-level Evidence}

\section{Paper 154}

Timothy F. Bresnahan

Erik Brynjolfsson

November 2000

Lorin M. Hitt

For more information, 


\title{
Information Technology, Workplace Organization, and the Demand for Skilled Labor: Firm-level Evidence
}

\author{
Timothy F. Bresnahan \\ Department of Economics, Stanford University \\ Stanford, CA \\ Timothy.Bresnahan@stanford.edu \\ Erik Brynjolfsson \\ Sloan School of Management \\ Massachusetts Institute of Technology \\ Cambridge, MA \\ erikb@mit.edu \\ Lorin M. Hitt \\ University of Pennsylvania, Wharton School \\ Philadelphia, PA \\ lhitt@wharton.upenn.edu
}

First Draft: January 1998

This Draft: November 2000

Forthcoming in the Quarterly Journal of Economics

JEL Categories: L200 Firm Objectives, Organization and Behavior: General; J230 Employment Determination; Demand for Labor; O300 Technological Change: General

\footnotetext{
${ }^{*}$ We thank David Autor, Gary Burtless, Lawrence Katz, Alan Krueger, Frank Levy, Paul Romer, three anonymous reviewers and participants at numerous seminars for valuable comments. We also thank executives at the firms in our sample for their participation and for valuable discussions. This research has been generously supported by the Center for Coordination Science and the Center for eBusiness at the Massachusetts Institute of Technology, the National Science Foundation (IIS-9733877), and the Stanford Computer Industry Project under grants from the Alfred P. Sloan Foundation and NationsBanc Montgomery Securities. Incon Research, the Center for Survey Research, Computer Intelligence InfoCorp, and Informationweek provided or helped to collect essential data.
} 


\title{
Information Technology, Workplace Organization and the Demand for Skilled Labor: Firm-level Evidence
}

\begin{abstract}
We investigate the hypothesis that the combination of three related innovations, 1) information technology (IT), 2) complementary workplace reorganization, and 3) new products and services, constitute a significant skill-biased technical change affecting labor demand in the United States. Using detailed firm-level data, we find evidence of complementarities among all three of these innovations in factor demand and productivity regressions. In addition, firms that adopt these innovations tend to use more skilled labor. The effects of IT on labor demand are greater when IT is combined with the particular organizational investments we identify, highlighting the importance of IT-enabled organizational change.
\end{abstract}




\section{Introduction}

Throughout the twentieth century significant shifts in labor demand have favored more skilled and educated workers [Goldin and Katz, 1999; Autor, Katz and Krueger, 1998]. The shift toward more skilled workers appears to have accelerated in the last 25 years relative to 1940-1973, especially over the period from 1980 until the mid-1990s. Over this period, demand has strongly shifted from low- and middle-wage occupations and skills toward highly rewarded jobs and tasks, those requiring exceptional talent, training, autonomy, or management ability. The overall effect has been both large and widespread, substantially shifting relative wages in the top, middle, and bottom of the income distribution.

While many factors have contributed to this increase in inequality, including a slowdown in the growth in the supply of skilled workers [Katz and Murphy, 1992; Card and Lemieux, 2001], an impressive body of empirical studies shows that a significant component of this effect is attributable to skill-biased technical change. ${ }^{1}$ Skill-biased technical change (SBTC) means technical progress that shifts demand toward more highly skilled workers relative to the less skilled. It also tends to be something of a residual concept, whose operational meaning is often "labor demand shifts with invisible causes." Not all technological revolutions increase the demand for skilled labor. For instance, the movement from skilled artisans to factory production in the 1800s probably reduced the demand for skilled labor, reflecting a complementarity between the new technologies and unskilled labor [Goldin and Katz, 1998].

However, the size, breadth, and timing of the recent labor demand shift have led many to seek SBTC in the largest and most widespread technical change of the current era, information technology (IT). IT is likely to be particularly important as computing technology increased in power and expanded its scope beyond back-office support to its current pervasive role in large firms. Quantitative research has already made it clear that there is a correlation - if not necessarily causation - between IT use and skill at the worker, ${ }^{2}$ firm, ${ }^{3}$ and industry ${ }^{4}$ level.

In this paper, we make advances on two fronts. First, we look inside the black box of the production function to forge a specific theory of how information technology is used in production. That story sharpens hypotheses about SBTC. Firms do not simply plug in computers or telecommunications equipment and achieve service quality or efficiency gains. Instead they go 
through a process of organizational redesign and make substantial changes to their service or output mix. This raises the possibility that computers affect labor demand not only directly, as has been previously studied, but indirectly through other firm-level changes. That is, IT is embedded in a cluster of related innovations, notably organizational changes and product innovation, which taken together are the SBTC that calls for a higher-skilled labor mix (Figure 1).

Second, we then examine new firm-level evidence to assess the new hypotheses as well as the most plausible alternative stories of the basic correlation between IT and skill. This not only confirms some of the findings of earlier work, but also enables us to empirically assess the role of firm-level factors like changes in work organization and examine some of the plausible alternatives to our theory.

\section{Framework}

Our theoretical framework is summarized in Figure 2, where we display the relevant observable factors in our analysis and the relationships among them. Most of the existing literature focuses on the relationship between declining IT prices, increased use of IT and a causally related increase in skill demand (the three boxes in the upper left of our diagram). Our approach introduces the additional role of complementarities among information technology, workplace organization, and product innovation as drivers of the SBTC. This approach introduces a number of additional mutually causal links, which we systematically analyze for the remainder of this section.

\section{A. Implications of Declining IT Prices}

The rapid and continuing decline in the cost of computing and increases in the power and variety of computer systems are an exogenous and powerful change in the environment of the firm. As computers have become faster, smaller, cheaper, more flexible, and easier to network together, the quality-adjusted real price of computers has been declining at a compound rate of about 20 percent per year through the mid-1990s. These changes and similar changes in technical complements to computers lead to very rapidly growing demand for IT. The growth in demand means that firms must regularly readjust their computer capital stocks.

The progress of IT investment at the firm level is not, however, smooth and direct. A substantial case- and interview-study based literature ${ }^{5}$ and a smaller econometric one ${ }^{6}$ has examined the causes of variety across firms in the pace and success of IT adoption. It points to 
complementarities among the use of computers, workplace organization, and output characteristics.

Better measurement and communication associated with IT change the information available within the firm. To the extent that the internal organization of the firm is determined by the economics of information and communication (e.g. Milgrom and Roberts, [1990]; Brynjolfsson and Mendelson, [1993]; Radner, [1993]) these technologies will change the optimal structure of the organization. The case literature reports a variety of such impacts: changes to authority relationships, decentralization of decision authority, shifts in the task content of clerks', operatives', professionals', and managers' work, and changes in reward schemes, among others [Bresnahan, Brynjolfsson and Hitt, 1999]. This is a source of complementarity between investments in IT and re-organization of the firm.

Surveys of managers and the case-study literature show that the most important reasons for investing in IT are product quality improvements, notably customer service, timeliness, and convenience [Brynjolfsson and Hitt, 1995, 2000]. Flexible machinery and organizational structures can efficiently supply a highly varied output mix [Milgrom and Roberts, 1990]. Organizational changes set off by IT investment are intended either to reduce cost or to improve product and service capabilities, although the latter is typically more important [Hammer, 1990; Davenport and Short, 1990; Brynjolfsson and Hitt, 2000]. Similarly, the combination of organizational and technological innovation is required to deliver consistently high levels of customer service [Davenport, 1994]. All this suggests a three-way cluster of complementarity among product quality improvements (broadly understood), re-organization, and IT investment.

While inventions that lead to improvements in IT are quickly available throughout the economy, complementary organizational changes involve a process of co-invention by individual firms [Bresnahan and Greenstein, 1997]. Identifying and implementing organizational coinventions is difficult, costly and uncertain, yielding both successes and failures. These adjustment difficulties and the experimentation and co-invention surrounding IT use lead to variation across firms in the use of IT, its organizational complements, and the resulting outcomes. The presence of adjustments costs for IT is well supported by both case studies and statistical analyses. ${ }^{7}$

The relationship between investment in IT and investments in its complements has a distinctive dynamic shape. In the long run, declines in the price of IT cause the demand for all the complements to shift out. In any particular short run, however, only a subset of firms will have 
made successful investments in organizations and product quality. Those firms will have particularly high demand for IT, and will be rapidly adjusting their IT stocks. Others will be waiting for an advance in co-invention or deterred by the costs of adjustment, and will have much lower demand (in the short run, at least) for IT. This view is a summary of previous work on technology and organization. Since the literature has not focused on labor demand effects (despite all of its focus on the reorganization of work) it has not examined the stock or flow of skilled and unskilled labor.

\section{B. Implications for Labor Demand}

The primary difference between our approach and previous work on computers and skillbiased technical change is that we look inside the black box of the firm at workplace organization and changing skills. In principle, IT could be a complement or substitute for skilled labor depending on how the technology is used. However, the literature on implementing IT in organizations also suggests two routes by which IT-intensive production might be more skillintensive, especially if the complementary changes to organizational practices are made [Bresnahan, 1999]. We call these limited substitution and information overload.

Computer business systems are most effective in automating routine and well-defined work tasks. That permits substitution out of certain kinds of human effort. Especially in record keeping, remembering, simple calculating, and similar tasks, IT use has led firms to systematically substitute computer decision-making for human decision-making in clerical (and similar routine) work. Advances in artificial intelligence notwithstanding, the scope of this substitution has been limited. Simple decisions, closely related to individual transactions or other operational actions, have been most amenable to computerization. More complex and cognitively demanding work, such as that of managers and professionals, has proved to be remarkably difficult to automate. ${ }^{8}$ Computer automation of such work has been correspondingly limited in its scope. Computer automation of clerical and blue-collar work typically does not directly substitute for all of a worker's tasks, but instead for a subset of ancillary tasks, and in particular, those that do not require exception processing, visual or spatial skills, or non-algorithmic reasoning [Autor, Murnane and Levy, 2000; Levy, Beamish, Murnane and Autor,1999].

Highly computerized organizational processes are often accompanied by a greater production of data. Raw data is fodder for analytic or abstract decision-making, such as analyzing customer needs to target new product development, heightening the value of skilled 
workers, managers and professionals (unless, as has rarely occurred so far, the computer system itself can make the analytical decisions). This will directly lead to a greater demand for skilled labor at the firm. However, because the rate of increase in data availability is typically larger than the ability of firms to adapt their labor pool (a situation referred to as information overload), firms must also make organizational adaptations to distribute information processing tasks. For example, firms may shift to a greater reliance on lateral communications and decentralized decision-making [Brynjolfsson and Mendelson, 1993] and have increased demand for employees who can work autonomously [Lazear, 1995, Bresnahan, 1999].

\section{Complementarity of Worker Skill and Organizational Change}

In addition, irrespective of the type of worker most affected, computers will generally change the way that human work is measured, controlled, or reported [Baker and Hubbard, 1999]. This will create a number of additional indirect flows from computers to labor demand, mediated by organizational change. Work may be restructured to allocate routine, well-defined symbol processing subtasks to computers while separating out subtasks requiring human skills. ${ }^{9}$ For instance, centralized databases enable individual workers to have the necessary information to complete an entire process that was historically fragmented, which shifts workers from a role of functional specialist to process generalist [Hammer, 1990]. In manufacturing, the use of flexible machinery and computerized process controls is often coupled with greater worker discretion, which in turn requires data analysis skills and general problem-solving ability.

The shift in incentives and work structures may also place greater demands on noncognitive skills. People vary in their taste or distaste for performance based incentives, which can be supported by computer-based measurement. People vary in their ability to work in teams. In parallel, the change calls for changed human interaction talents in supervisors. For instance, supervisors will need more skills in dealing with customers and suppliers, influencing teammates and colleagues, and inspiring and coaching subordinates [Brynjolfsson, Renshaw, and Van Alstyne, 1997]. More generally, the changes involve providing the "people skills" that computers lack.

The invention of new products and adaptation to new organizational forms itself requires greater levels of cognitive skill, flexibility and autonomy than in traditional employee roles where the production process is fixed and includes limited discretion. [Bartel and Lichtenberg, 1987] suggest that cognitive skills may be important in adapting to change generally, notably in the 
adoption of new technologies. Adaptation to IT-based change may be a standing requirement of the modern firm, resulting in a lasting shift in labor demands.

\section{Putting the Hypotheses Together}

Our economic hypothesis is a complementary relationship at the firm level between labor demand behavior and (i) computerization; (ii) computer-enabled organizational change; and (iii) new computer-enabled forms of output. This cluster of inventions, playing out over multiple years and across many firms, constitutes the technical change that is associated with an increased demand for skilled labor. While improvements in IT are an important causal force in this story, it is the cluster which is key, since IT use is more likely to be effective in organizations with a higher quality of service output mix, decentralized decision-making and more skilled workers. Firms that invest heavily in IT should also be more likely to adopt our hypothesized set of complements. Furthermore, those firms that successfully combine these elements would be predicted to produce more valuable output than their competitors.

Turning now to measurement, our econometric approach exploits the fact that these complements are associated with different adjustment costs and adjustment speeds. We can therefore examine the relationship between the slower-changing choices (e.g. workplace organization) and the faster-changing ones (training and hiring practices for labor, computer adoption) to measure complementarities. For the complementarities theory, it does not matter whether we think that "computers cause skill" or "skill causes computers": if they are complements, long-run changes in the price of one cutting across all firms will affect the demand for both. Thus the complementarities theory can be investigated in either causal direction, depending on which is more appropriate to ensure that it truly is complementarities that are being measured, not some other force.

Each of the three complements is associated with an observable variable or variables. Our treatment of improvements in the quality of output is based on the point that changes in product characteristics are difficult to measure in a broad cross section of firms. However, those firms that succeed in product innovation will earn quasi-rents, which will appear as increased dollar sales relative to the sales of other firms controlling for input consumption. Similarly, workplace organization in general is quite difficult to measure, but we have new survey results at the firm level that we link to our hypotheses. Finally, our measures of the skill mix of labor demand and of computer capital stocks and flows are very conventional. 
While earlier studies emphasized a direct causal link between information technology and labor demand, an empirically relevant distinction in our theory is the addition of workplace organization as a central part of the complementarity. The interactions with workplace organization, while critically important, are observable only with detailed firm-level data.

\section{Data Description}

Our data set matches three sources: (1) a panel detailing IT capital levels and mix over the 1987-1994 period; (2) Compustat measures of other production function inputs and outputs over the 1987-1994 period; and (3) a cross-sectional survey of organizational practices and labor force characteristics. The cross sectional survey was conducted in 1995 and 1996 . Once firms with any missing data are removed, we are left with approximately 300 large U.S. firms in our sample. Here we briefly describe each data source and our measures of key variables, with supplementary details in the Appendix. ${ }^{10}$

\section{A. Data Source: Workplace Organization and Labor Force Characteristics}

We surveyed senior human resources managers in three waves in 1995-1996. Our 14 questions were largely drawn from prior surveys on workplace organization and human resources practices (see Huselid [1994]; Ichniowski, Shaw and Prennushi [1997]; and Osterman [1994]). Short definitions, variable names used in formulas and tables, and descriptive statistics can be found in Table I. The survey offers a snapshot of work organization and related variables at the end of our analysis period.

The universe of potential respondents was limited to firms that reported both computer capital data from Computer Intelligence InfoCorp (essentially the Fortune 1000) and input and output data on Compustat. This yielded a total population of 778 firms that were contacted by telephone to yield 379 survey responses (a response rate of 48.7 percent). Approximately 55 percent of the observations are from manufacturing, mining, or construction firms and 45 percent are in services. The firms in our sample are also broadly representative of the large firms available in Compustat, although there are some deviations - a slight overrepresentation in the finance sector, offset by a lower number in "other services" (see appendix C for details).

We asked the responding managers questions about the labor force at two levels of aggregation: the firm, and its "most typical" establishment. ${ }^{11}$ 
This survey provides us with a rich set of measures related to the demand for human capital (HK). We proxied the firm's skill demand in three ways. The first two relate to the production workers in the firms' typical establishment:

- Education mix. Percentage of the production workers with high school education or less (\%HSED), some college, and completed college (\%COLL).

- Worker Skills. The responding manager's assessment of production worker skills (on an arbitrary scale of 1-5) (SKILL).

In addition, we have five occupational measures that collectively capture the distribution of skills across the entire firm, as percentages:

- $\quad$ unskilled blue collar $(\% U S)$, clerical (\%CL), skilled blue collar (\%SK), managers (\%MG) and professionals $(\% P F)$. We also define the percentage of information workers $(\% I W)$ as the sum of clerical, managerial and professional worker percentages.

Descriptive statistics in these variables and variable names used in the tables can be found in Table I. Clearly, they measure distinct but related aspects of a firm's stock of human capital. All of these aspects are likely to be quasi-fixed in the short run at the firm level.

The firm can adjust human capital investment policies far more rapidly than its actual stock of human capital. This leads us to construct a further variable measuring these policies, called HKINVEST. We base it on the importance of screening for education in hiring (SCNED), the fraction of workers receiving training (TRAIN) and the importance of cross training (XTRAIN). Here, as elsewhere, we standardize by subtracting means and dividing by standard errors.

Let the definition of STD $(x)=(x-\bar{x}) / \sigma_{x}$.

$$
H K I N V E S T=\operatorname{STD}(\operatorname{STD}(S C N E D)+\operatorname{STD}(T R A I N)+\operatorname{STD}(X T R A I N))
$$

The same survey lets us define a measure of the decentralization of workplace organization at the firm's typical establishment. Our measure takes into account four related measures of the importance of self-managing teams among the production workers. These measure (1) team use (SMTEAM); (2) team-building activities (TEAMBLD); (3) teamwork as a promotion criterion (PROMTEAM); and (4) the use of employee involvement groups or quality circles $(Q U A L C I R)$. Two further measures concern the allocation of decision authority between these workers and managers. PACE is higher when workers decide on the pace of work; 
METHOD is higher when they decide on its methods. Altogether, we define our decentralized workplace organization variable as

$W O=\mathrm{STD}(\mathrm{STD}(S M T E A M)+\mathrm{STD}(T E A M B L D)+\mathrm{STD}(P R O M T E A M)+\mathrm{STD}(Q U A L C I R)+\mathrm{STD}(P A C E)+\mathrm{STD}(M E T H O D))$

We chose this variable for several reasons. Our specific definition of $W O$ has been found to be a useful summary metric - the only non-noise factor in a principal components analysis - in

earlier work by [Hitt and Brynjolfsson 1997]. ${ }^{12}$ Second, it has an obvious economic interpretation in terms of decentralizing decision-making to teams. Finally, $W O$ as a concept of workplace organization is relatively narrow and specific. This makes our model and econometrics more precise and interpretable, although $W O$ is probably not catching all of the relevant organizational changes.

Since our data on organizational characteristics are based on a snapshot at the end of the sample period, we do not know whether each firm had the same organizational characteristics throughout the sample period. Nonetheless, the dynamics of $W O$ are reasonably clear. It is likely that many of the firms were in the process of adopting these practices during the sample period. ${ }^{13}$ In a measurement sense, much of the $W O$ that we measure reflects changes in $W O$ over the sample period. Work organization is hard to change but has nevertheless been changing toward the set of practices we label $W O$.

\section{B. Data Source: Information Technology}

Our measures of IT use were derived from the Computer Intelligence Infocorp (CII) installation database. CII conducted a telephone survey to inventory specific pieces of IT equipment by site for firms in the Fortune 1000 (surveying approximately 25,000 sites). For our study, CII aggregated types of computers and sites to get firm level IT stocks. They calculated the value of the total capital stock of IT hardware (central processors, PCs, and peripherals) as well as measures of the computing capacity of central processors in millions of instructions per second (MIPS) and the number of PCs. The IT data do not include all types of information processing or communication equipment and are likely to miss a portion of computer equipment which is either purchased by individuals or departments without the knowledge of information systems personnel, or owned or operated off-site. The IT data also exclude investments in software and applications. Descriptive statistics can be found in Table II and more detailed discussion in the Appendix. 


\section{Data Source: Other Inputs and Sales}

We used Compustat firm data to calculate employment levels and labor expense, sales, capital, and value added in constant 1990 dollars. We also used Compustat to assign firms to an approximately 1.5-digit SIC code industry. ${ }^{14}$ Table III provides descriptive statistics and Appendix Section B provides more discussion.

Some firms provided only partial data or were missing data from Compustat, reducing the sample size for many of the analyses below. Our analyses are primarily based on the common sample that has complete data for our core measures. This includes a total of 1331 firm-years of data; ${ }^{15}$ analyses based on long differences or cross sections typically use 250 firms.

\section{Product and Service Innovation}

The most difficult change to observe in terms of the cluster of technological changes is the change in product and service quality and the invention of new products and services. A firm's success may be one observable indicator of these changes. Firms with higher quality output for a given set of inputs will likely have greater sales, reflecting a price premium, greater quantities demanded or both. This will be measured as relative differences among firms in the same industry in multifactor productivity.

\section{IV.Empirical Methods}

Using the firm-level data, we can test several implications of our hypothesis that the complementary system of IT, decentralized work organization, and innovations in output is in turn complementary with skilled labor. Our data are a mixture of a panel (the CII and Compustat data) and a cross section of organizational and human capital variables observed at the end of the sample period. We can examine cross-sectional relationships at the end of the sample. We can also examine the relationship between the changes over time in some variables and the state of the firm at the end of the sample.

Our strategy is to look at (1) correlations across firms in the use of the hypothesized complements; (2) short-run conditional input or technology choice equations; and (3) simple production functions. Taken together, these analyses are surprisingly informative not only about complementarities but also about alternative interpretations. We use the following basic notation. $Q_{c i t}$ is a measure of firm i's choice of one of the hypothesized complements (either an input or a 
technology) in year t of input $c$; the different $c$ s are IT capital, work organization, and human capital measures.

The short-run input choice functions are of the form

(1). $\quad \mathrm{Q}_{\text {cit }}=\mathrm{f}\left(\mathrm{Q}_{\text {c'it }}\right.$, Controls $)$

On the left, we put the $\mathrm{Q}_{c}$ that are easier to vary. $Q_{c^{\prime} i t}$ are measures of the firm's choices of the other inputs/technologies (and hypothesized complements) $c^{\prime}$. This is a short-run conditional choice equation because it predicts the more easily varied choices, $c$, as a function of the others, $c^{\prime}$,

which are fixed or quasi-fixed at the firm level. ${ }^{16}$ Controls include firm size, industry, and production process proxies. Our interpretation is that $c$ is demanded more when the $c^{\prime}$ are particularly high because they are complements, i.e., because $Q_{c}$ is more productive when used together with $Q_{c}$.

We also estimate production functions of the form

(2). $\quad \log \left(\mathrm{S}_{\mathrm{it}}-\mathrm{M}_{\mathrm{it}}\right)=\mathrm{f}\left(\mathrm{L}_{\mathrm{it}}, \mathrm{K}_{\mathrm{it}}, \mathrm{Q}_{\text {cit }}\right.$; controls $)$;

where $\mathrm{S}$ is sales, and $\mathrm{M}$ is the materials bill, so that the dependent variable is $\log$ (value added). Labor and capital are measured in the logs, as well. Our measures of the three potential complements $\left(Q_{c i t}\right)$ are entered as levels and interactions with one another. Controls include industry and time. Our interpretation of this production function is that the levels of $Q_{c i t}$ reflect the degree to which the firm has adopted information technology and new forms of work organization and the degree to which the firm tends to use more highly skilled labor. The interactions address complementarities among those choices. In the case of process technical change, the production function interpretation is direct. In the case of product technical change, the interpretation is relative; a firm with a better product will take customers away from competitors and have higher sales in Equation 2. We can only measure differences in technical progress between firms; if all firms advance together it cannot be measured in Equation 2.

\section{A. Alternative Explanations}

These techniques could measure firm-level complementarities even when there is a nonproductivity explanation of the tendency for firms to use $c$ and $c^{\prime}$ together. Careful interpretation of a variety of results helps differentiate between productivity and alternative explanations.

One alternative is that the use of $c$ and $c^{\prime}$ is simply a coincidence. Unobserved shocks to the value of each of the "complements," correlated in the cross section of firms, would explain the 
correlation among the hypothesized "complements" and, in some circumstances, explain the conditional input choice results in Equation 1. If the same shocks are correlated with productivity, they can explain the Equation 2 results as well [cf. Athey and Stern, 1998].

The simplest coincidence story is one of an error in aggregation. Human capital, computers, and decentralization each might simply be more useful in some kinds of industries or in some kinds of firms within industries. These might also, coincidentally, be the more productive ones.

Some firms might have luck or skill -- demand shocks or efficiency advantages (not caused by the complementarities). Such firms might use more of each input and have higher measured productivity. A systematic force that leads such firms to use more of the supposed complements would be an alternative. Systematic forces could be:

- The expansion path of inputs as the scale of output rises. Bigger firms buy more of the "complements."

- Managerial rents and free cash flow might lead successful firms to demand more of these particular inputs. Managers might take pleasure from working with smarter and more capable people, and so on.

- Worker rents. Rather than computerization and skills being complements, the causation operates in the reverse direction and is unrelated to productivity. For example, skilled workers might get computers for fun. ${ }^{17}$

Another possibility might be a fad: some managers might have decided that all three of the complements are useful, with no particular foundation, while others hold back. This should show up in demand but not productivity. A very different kind of "alternative" posits that we are missing some important complementary inputs, such as applications software. Those omitted inputs raise the value of human capital, decentralized work organization, and IT. The econometric interpretation problem this raises is not an economic interpretation problem for us, since this theory is simply a more elaborate version of our basic story. A related story is about causation: rather than computerization causing an increased demand for skills, instead the more firms with skilled workers find computers more productive and buy more of them. That is simply just another version of our story. Such reverse causation -- associated with productivity -- is also complementarity at the firm level. In the long run, as computers grow cheaper, firms will find it in 
their interest to have skilled workers. We will seek to address and disentangle these alternatives in our empirical work.

\section{Empirical Results}

\section{A. Correlations}

We find that the complements covary in cross-section / time series data. In Table IV, we report the Spearman rank correlations among a high-level measure of workplace decentralization, $W O$, the log of the firm's total IT capital stock, and selected human capital measures. As with many of our analyses, these correlations are within (broad) industry classes and hold constant both firm size (employment) and the occupational composition of the principal production workers in each firm $(P R B L, P R C L)$. The last control is for the production process; firms whose production workers are professionals or clerical workers may be very different than those whose production workers are blue collar. Every one of the correlations is positive, though a few are small economically or statistically. Not all the human capital measures are correlated with one another or with IT or $W O$, but $W O$ is highly correlated with all the other variables.

Looking behind those broad measures, we see that a variety of alternative measures of IT are significantly correlated with several measures of employees' human capital (Table V). The correlation is stronger when the measures of IT are taken from the same organizational survey as the human capital data (first three columns) than when we use the IT measures from the separate CII survey. This probably reflects a better match of the unit of observation. ${ }^{18}$ The correlation is visible whether we measure human capital by managers' assessments of skills and education requirements, by the educational composition of the workforce, or by occupational composition. Firms that have fewer high-school-educated workers and/or more college-educated ones tend to have more IT. Firms which employ more managers and especially professionals are more likely to have high levels of IT while those with more blue collar workers tend to have less IT. Once again, we are controlling for industry, size, and process.

The same table also shows how the IT measures are correlated with policies for greater investments in human capital, such as training and screening new employees on the basis of their education (Table $\mathrm{V}$, lower rows). The result is less consistent for our other measure of human capital investment, cross-training $(X T R A I N)$. IT can also predict greater investments in human 
capital (HKINVEST) even when we control for current levels of human capital (by including SKILL and EDUC as partial covariates as shown in the bottom rows of the table).

We also find that decentralized workplace organization is correlated with employee human capital however it is measured (Table V), and (in results not shown) with firms' attempts to increase human capital via pre-employment screening. Other results not shown here (but reported by Brynjolfsson and Hitt, [1997] in a restricted sample) reveal positive correlations of various measures of IT with our summary measure of decentralization, $W O$, and with the measures that underlie it.

The correlations among IT, human capital and $W O$ are consistent with the view that all three are complements or that the same underlying causes or coincidences drive all three.

\section{B. Firm-level demand for IT}

Since the easiest-to-vary of the factors in the cluster of complements is computer capital, we first estimate a series of firm-level short-run demand equations for IT. We see how the relatively fixed factor of human capital and the relatively fixed technology variable of organization predict the more easily variable IT. Our main interpretation of the coefficients of the relatively fixed variables will be as evidence about complementarities, but we will also consider other hypotheses.

We estimate Equation 1 for (log) IT capital stock in a firm as a function of (log) firm value added, (log) firm employment, production process (proxied by primary production worker occupation), our human capital proxies, $W O$, industry and year. Under our hypotheses, $W O$ or human capital or both should predict the firm-level demand for IT.

In Table VI, we present estimates of several variants of this IT demand equation. In a very lean specification, we see that firms with a one standard deviation higher level of (production worker) skill have about a 14.2 percent higher IT demand (column 2). When a variable is added to this equation for workforce organization (column 3) we find that it too is substantial and significant. Moreover, the skill effect and the organizational effect are roughly the same order of magnitude (each is measured as standardized deviations from means). Our interpretation is that both are complements with IT. Adding $W O$ reduces, but not to zero, the coefficient on skill; since $W O$ and skill are also complements with one another, they covary positively. Similar results appear when we add additional controls for the percentages of college-educated workers (column

3). However, when we add additional measures for occupational composition of the workforce the 
direct effects of education are substantially reduced (not shown). Given that our workforce composition measures (a firm level construct) are highly collinear with production worker education, this suggests that we are capturing a general firm-wide effect of human capital. It is not clear that we can distinguish any specific human capital measure from the others or make a clear distinction of human capital at the firm overall versus human capital of a specific group of employees.

In our regressions, we can distinguish human capital measures from $W O$, which has roughly the same positive effect however human capital is measured (columns 2,3), so it appears that demands for high levels of skill and workplace organization are empirically as well as conceptually distinct. Several of the alternative interpretations depend on mechanisms in which all investment should be high in the firm because the correlation in the inputs is induced by success. Column 4 of Table VI has the same specification as Column 3, except that the dependent variable is changed from IT capital to non-IT capital. While workplace organization and human capital are good predictors of IT, they are weak predictors of the demand for other types of physical capital, highlighting the special relationship among IT, WO and human capital. We should also note that the inclusion of the sector and production process (production worker composition) variables inError! Reference source not found. Table VI undercuts the aggregation error story that it is simply variety in circumstances that lead to $W O$, IT, and human capital together. It still may be, but it is the within-industry, within-process variety.

\section{Human Capital Investment Policies}

If new forms of work organization and IT together represent the skill-biased technical change, they should also predict skill demand. Not all versions of such an analysis can be reliably undertaken, however, because of the dynamics of factor demand: a firm's stock of human capital is quasi-fixed. Policies related to the recruitment and training of workers, however, can be quickly varied. The versions of Equation 1 reported in Table VII predict our index of policies toward human capital investment (HKINVEST) in the cross-section of firms. Complementarity suggests that IT and workplace organization should affect the demand for human capital investments such as training and the screening of new workers by education.

A spurious correlation could arise if "lucky" firms, those with particularly high efficiency or demand, invest more in more highly skilled workers and, separately, in computers for reasons other than complementarity. Our specification deals with permanent "luck" because it is implicitly 
differenced: HKINVEST is a measure of the rate of change in human capital, not the level. We deal with transitory luck by using the IT variables with four-year lags or by using lagged values as instruments. ${ }^{19}$

Under a variety of specifications of IT, we find that both work organization and IT per worker predict HKINVEST, human capital investment policies (Table VII), after controlling for existing human capital levels (SKILL) and sector. Firms with high levels of IT and WO use high HKINVEST strategies, whether or not they already have a great deal of human capital, and the effect is a within-sector one rather than reflecting only differences in production process between sectors. Our findings for IT are quite similar to industry-level findings by [Wolff, 1996 and especially Autor, Katz and Krueger, 1998] in their Table VII. Using industry-level data, they find that the annual change in the college wage bill share is positively related to present and past levels of computerization. In addition to finding a similar relationship (here with HKINVEST, not wage bill share, as the dependent variable) in firm-level data, we also identify an important role for workplace organization. The $W O$ effect is systematically large and precisely estimated. Given the dynamics of $W O$, the obvious interpretation is that recent changes in workplace organization leave the firm in a position where it needs to adjust its stock of human capital upward.

Some of the contrasts across the specifications are worth noting. First, comparing Col ( 1) $\operatorname{Col}(1)$ and $\mathrm{Col}(2)$, we see that the existing level of human capital (SKILL) predicts HKINVEST only if $W O$ is omitted. Second, the coefficients change very little when current levels of IT are instrumented with past levels of IT instead of using the lagged values of IT (contrast Col(2) with Col(3)). One might interpret these two results to mean that the human capital and IT investments are not a reaction to a short-run free cash-flow shock, but instead reflect a long-run iteration of the complements moving together. When we change the measure of IT to a question about the computer-intensity of work tasks $(C O M P)$, the coefficient is significantly higher but also less precisely estimated. One might interpret this to mean that broad measures of IT (like ITCAP, MIPS or TOTPC) include both systems tightly connected to the work of the organization and other systems that affect few jobs. ${ }^{20}$ In $\mathrm{Col}(5)$ and $\mathrm{Col}(6)$ we change the measure of computer intensity to MIPS and TOTPC, respectively. The MIPS results are much like those we obtained using ITCAP. However, PCs are a relatively weak predictor of HKINVEST. We interpret this to mean that it is organizational, not personal, computing that predicts HKINVEST in this time period, just 
as it was the form of computing most strongly predicted by the human capital and $W O$ variables above.

\section{Complementarities in the Production Function}

Complementarities imply increasing marginal returns to $Q_{c}$ as its complements $Q_{c}$, rise. We attempt to measure these effects in a production function context. This strategy will not always work to measure complementarities. If all firms' production functions had the same complementarities among IT, workplace organization, and human capital, and if there were no adjustment costs or mistakes in implementing these strategies, then the three complements would covary highly in a production function regression. Firms' optimizing behavior would have already avoided combinations such as "low-IT, and high-human capital," thereby removing crucial identifying variation from the production function regressors.

In the present inquiry, that argument is considerably less problematic than usual. Indeed, we have just seen that firms in our sample do demand more of one of the complements when the others are high. Two of the complements are subject to large adjustment costs, as we have seen. Furthermore, exploitation of the complementarities involves invention by the firm and so is characterized by routine experimentation from an ex ante perspective and frequent "mistakes" from an ex post one. ${ }^{21}$ We expect to find enough incompleteness in firms' exploitation of the complementarities to measure them in the production function. This approach provides a valuable counterpart to the demand analysis, which provides the strongest results when all firms are successfully exploiting the complementarities.

The production functions reported in Table VIII include controls for industry and year and three types of productive inputs: labor, IT capital, and non-IT capital. Table VIII shows that both IT and various measures of human capital tend to contribute to output separately; however, they are associated with greater increases in output when the level of the other one is also high, which is consistent with complementarities. $^{22}$

The levels of human capital, IT, and WO measure the return to use of those technologies at the center of the sample. All columns continue to show the now-familiar finding in firm-level data that IT is measured as highly productive. Like our predecessors, we interpret this as showing the large adjustment costs to the successful use of IT [Brynjolfsson and Hitt, 1996; Brynjolfsson and Yang, 1997] - adjustment costs likely located in work organization or other co-invention, not in installing the IT itself [Bresnahan and Greenstein, 1997]. The story for human capital is more 
ambiguous, depending on the measure we use; "skill" has an approximately zero coefficient, while the coefficient on the percentage of professionals is positive and larger, although both are insignificant.

The Table (column 4) shows the new finding that $W O$ is also associated with high measured productivity, although the statistical significance of this finding depends on the sample and the other regressors, but is consistent in magnitude. The interpretation is the same as for IT -substantial adjustment costs are associated with the new organizational technology, proxied by $W O$, and the firms that have overcome these adjustment costs by luck or good judgment have high measured productivity.

The interaction terms between IT and human capital are positive and substantial for skill, college education, and professional employment (not shown). The point estimates are economically large, as the measured output elasticity of IT on any of these three measures is substantially higher in firms with more skilled workers. This goes to the economic hypothesis of complementarity, and in a way that provides evidence against "fad" and other nonproductive explanations of the co-movement of the complements. However, we are cautious about interpreting the size of the coefficients in these regressions, given that there are likely to be correlations between our included variables and unobserved productivity enhancing factors. While this is just a more elaborate form of complementarity, consistent with our theory, it does limit the ability to calculate the marginal productivity contribution of any particular factor. In addition, the coefficients are not measured all that precisely. For example, SKILL* $\log (I T C A P)$ is only of borderline significance, though the college education interaction effect is somewhat stronger statistically. Given the collinearity among the various complements, our sample is only just large enough to identify this effect; comparisons across different subsamples are remarkably robust in magnitude but vary in significance level. The limits of the data are clear when we consider all possible interactions between IT, human capital and WO - the coefficients are all positive, but none are precisely estimated (not shown).

The interaction specifications permit us to undertake some simple predicted-productivity calculations that are illuminating. Consider a firm that might be two standard deviations away from the means for industry and year on any or all of the human capital, $W O$, and IT axes. The predicted values indicate that a firm that is high on all three axes has very high predicted productivity -- approximately 7 percent above a firm that is at the mean on all three, excluding the 
direct effect of higher IT capital. Interestingly, this is on the same order as the productivity changes associated with various workplace innovations found by Black and Lynch [1997] using a sample of 627 plants during a comparable time period (1987-1993). Their regression coefficients suggest that the cumulative effect of introducing a set of changes including computerization, workplace meetings, self-managing teams, and profit-sharing incentives would be a labor productivity increase of 11 percentage points. However, while they discussed the potential for complementarities among technology and organization, they did not report any interaction terms between computers and the various work practices.

If we change to the "mixed" cases (high-low-high, etc.) we find that the predicted productivity falls to worse than the mean in almost all cases. The very interesting case of low-lowlow is exceptional; it has about the same predicted productivity as the mean, a good bit higher than that for many of the "mixed" cases. This is consistent with the complementarities notion. There is a perfectly workable group of low-low-low, old-style firms. They have internal consistency in their mix of complements, what Milgrom and Roberts [1990] call a "coherent combination" of practices. Importantly, this result argues against heterogeneity arguments as an explanation for the results. While some unobserved firm-level shock, such as free cash flow, could yield positive effects on human capital, IT, and productivity all at the same time, it is difficult to explain why firms with low IT, low human capital and low $W O$ have higher productivity than those with one but not the others. ${ }^{23}$

\section{E. Managers' Beliefs}

When it comes to assessing causality, social scientists have one advantage over natural scientists: we can ask our subjects why they do what they do. The subjects may or may not fully understand the causality themselves, but at a minimum, they can provide insight into their motivations. Our survey asks managers' opinions on the effects of information technology on work. The managers rate the importance of each of several different effects on a scale of 1-5.

Their responses let us ask two kinds of questions. First, what do managers think are the important effects on average? This uses managerial opinion the way we often use anecdotes, case studies, and interviews. ${ }^{24}$ Second, if managerial opinion is heterogeneous, which views are associated with actual investment in IT, human capital or WO? Since we hypothesize that the heterogeneity in firms' levels of IT, human capital and work organization is in part driven by 
differences in managerial beliefs about what investment levels are optimal, we can examine this hypothesis directly.

The central tendency of opinion among the responding managers is that computer use increases the need for skilled workers (Table IX, first row, first column); that computers tend to increase workers' autonomy; and that computers increase management's need and ability to monitor workers. Thus, the people who are making the investment decisions in IT, human capital and $W O$ do seem to detect a complementarity among them. On average, they do not believe that computers are deskilling or reduce worker autonomy in their firms, as is sometimes hypothesized.

We examine the correlation of these managerial opinions with firm choice variables in the rest of Table IX . This first column stands out; managers' opinions about IT and skill requirements are strongly associated with increased adoption of IT-organization-human capital cluster. Managers are clearly thinking in terms of the relationship between technical progress and skill demand when they invest in human capital, organizational decentralization, and IT.

We see three explanations for the fact that managers in firms that adopt the new work practices are more likely to detect a complementarity between IT and skilled work. They may have more experience with the new work system (in which case we might judge their assessments to be more accurate); they may be acting on their beliefs by investing more in clusters of complements than their competitors (in which case we have identified one of the sources of heterogeneity); or some additional hidden factor may be driving both sets of variables (in which case we have only taken a partial step toward sorting out the chain of relationships).

\section{VI.Conclusion}

Earlier work found evidence that computers and skilled labor are relative complements in data at the industry (e.g. Autor, Katz and Krueger, [1998]; Berman, Bound and Griliches, [1994]) and establishment level (e.g. Doms, Dunne and Troske, [1997]; Black and Lynch, [1997]). In this paper, we find firm-level evidence that is consistent with the existing literature. In addition, we specify and test a new theory of skill-biased technical change in the contemporary economy using firm-level data. Skilled labor is complementary with a cluster of three distinct changes at the firm level: information technology, new work organization, and new products and services.

We identify a number of testable implications of this theory and examine them in a variety of empirical analyses on firm-level data. Since some of the complements are associated with 
considerable adjustment costs at the firm level (notably work organization and to a lesser extent human capital) while others are getting much cheaper over time (IT) we expect firm heterogeneity in the adoption of these complements, both individually and as a cluster. With regard to the inputs, this implication is strongly born out. IT, $W O$, and human capital are positively correlated, with or without controls for industry and process heterogeneity. The quasi-fixed choices (work organization and human capital levels) are good predictors of the demand for the more variable ones (IT stocks, IT investment, or human capital investment).

On the output side, new products and services are very hard to measure directly in a firmlevel dataset covering much of the economy. We believe the firms that are unusually productive are the ones that have overcome the adjustment costs in product or process innovation, and find that IT, $W O$, and human capital interactions (but not always levels of these variables individually) positively predict firm productivity. These results are consistent with the existing literature on IT and organizational change, with predictions of information-economics-based theories of the firm, and with the perceptions of the effects of IT expressed by managers in our sample.

We also examine several alternative explanations not involving productive complementarities between skill and the cluster. While each particular alternative may explain some of our reported results, no single alternative story is consistent with all the empirical results. If these relationships were merely a managerial fad, the inputs in the cluster would covary with skill, but would not predict firm performance. Demand shocks might increase investments in all inputs and also lead to increased measured productivity. This seems unlikely to be the explanation, as none of our measured effects are present for other types of investment (non-IT capital). Evidence of complementarities persists when we control for industry sector and production process, undermining the aggregation error hypothesis. Finally, while personal computers or increasingly skilled workers may be a way for managers or workers to consume rents, the strongest effects we measure are due to organizational change and investments in organizational computing such as mainframes. Neither of these is likely to be a consumption good.

Scenarios in which managers of successful firms simply choose to make simultaneous investments in the factors we identify and not in others are consistent with all the results, but are also perfectly consistent with our original explanation. Making reasonable allowance for some of the limitations of our data and for the difficulty of estimating complementarities from a direct 
production function, there is strong evidence for the cluster-of-complementarities theory of skillbiased technical change, and substantial evidence against other theories.

Our analysis has implications for understanding skill-biased technical change over the last quarter century. First, we provide new evidence, based on firm-level data, that information technology is a source of increased demand for skilled labor and rising wage inequality. While our tables refer only to the 1987-1994 period, it is clear from the literature on the uses of information technology that many of the same effects have been going on since well before the sample period and are likely to continue past it as well. Second, we identify an important set of mechanisms by which labor demand is influenced through organizational redesign. Organizational changes induced by technical change may have a much larger effect on skills than raw technical change. The kinds of organizational change that are complementary to information technology are widespread throughout the firm, and invention of these organizational changes and associated output market improvements are an innovative activity widespread throughout the economy. As information technology grows cheaper and more powerful, it induces more and more complementary investment in the rest of the cluster of changes -- most importantly, for our present purposes, in skilled labor. 


\section{Appendix: Data Details}

\section{A. Computer Intelligence Infocorp variables}

IT Capital (ITCAP). We take the total purchase value of computer equipment as reported by Computer Intelligence Infocorp. (CII) and deflate it using an extrapolation of Gordon's [1990] deflator for computers (price change - 19.3 percent per year). The total purchase value represents the current market value of mainframes, minicomputers, and peripherals, as well as personal computers during the 1991-1994 portion of our sample period. Prior to 1991, the purchase value only represented the value of mainframes, minicomputers, and peripherals, but excluded personal computers.

Central Processing Power (MIPS). This variable is taken straight from the CII database and represents the total processing power of central processors, measured in millions of instructions per second (PCs are not included in this calculation).

Personal Computers (TOTPC). This is also taken straight from the CII database and represents the total number of personal computers in use at the firm.

\section{B. Compustat-based variables}

Sales (SALES). Total Sales as reported on Compustat [Item \#12, Sales (Net)] deflated by 2-digit industry level deflators from Gross Output and Related Series by Industry from the BEA for 1988-1992, and estimated for 19931994 using the five-year average inflation rate by industry. When an industry deflator is not available, we use the sector-level producer price index for intermediate materials, supplies, and components [Council of Economic Advisors, 1996].

Ordinary Capital (NITCAP). This figure was computed from the total book value of capital (equipment, structures, and all other capital) following the method in [Hall 1990]. Gross book value of capital stock [Compustat Item \#7 - Property, Plant and Equipment (Total - Gross)] was deflated by the GDP implicit price deflator for fixed investment. The deflator was applied at the calculated average age of the capital stock, based on the three-year average of the ratio of total accumulated depreciation [calculated from Compustat item \#8 - Property, Plant \& Equipment (Total - Net)] to current depreciation [Compustat item \#14 - Depreciation and Amortization]. The calculation of average age differs slightly from the method in [Hall 1990] who made a further adjustment for current depreciation. The constant dollar value of IT capital (as calculated above) was subtracted from this result. Thus, the sum of ordinary capital and IT capital equals total capital stock.

Labor Expense (LABOR). Labor expense was either taken directly from Compustat (Item \#42 - Labor and related expenses) or calculated as a sector average labor cost per employee multiplied by total employees (Compustat Item \#29 - Employees) when labor expense was not available, and deflated by the price index for Total Compensation [Council of Economic Advisors, 1996]. The average labor expense per employee was taken from BLS data on the hourly cost of workers (including benefits) for 10 sectors of the economy. For firms which had labor expense directly reported on Compustat which did not include benefits (identified by Compustat Item - Labor Expense Footnote), we adjusted the labor figure by multiplying the reported labor expense by the total compensation/wages ratio for each sector as reported by BLS.

Employees (EMPLOY). The number of employees was taken directly from Compustat (Item \#29 - Employees). No adjustments were made to this figure.

Materials (MATL). Only used in computations. Materials was calculated by subtracting undeflated labor expenses (calculated above) from total expense and deflating by the industry-level output deflator. Total expense was computed as the difference between Operating Income Before Depreciation (Compustat Item \#13), and Sales (Net) (Compustat Item \#12). 
Value-Added (VA). Computed from deflated Sales (as calculated above) less deflated Materials.

Sector Dummy Variables. The industry controls used in most analyses in this paper correspond to an intermediate level between 1-digit and 2-digit SIC codes. Based on the reported primary SIC code on Compustat, we construct the following variables:

Mining /Construction (MI) - SIC 11xx - 20xx

Process Manufacturing (PR) - SIC 26xx, 28xx and 29xx

Other Non-Durable Manufacturing (MN) - SIC 20xx - 23xx and SIC 27xx

High Technology Manufacturing (HI) - SIC 36xx - 38xx and 3571 (computers)

Other Durable Manufacturing (MD) - SIC24xx-25xx, 30xx-35xx (except 3571) and 39xx

Transportation (TP) - SIC40xx-47xx

Utilities (UT) - SIC48xx-49xx

Trade (TR) - SIC50xx-59xx

Finance (FI) - SIC 60xx-69xx

Other Services (SR) - SIC70xx-79xx

\section{Survey Characteristics}

\begin{tabular}{|l|c|c|}
\hline & Sample & $\begin{array}{l}\text { Other Fortune 1000 } \\
\text { companies in CII and } \\
\text { Compustat data sets }\end{array}$ \\
\hline Value Added & $\$ 971$ & $\$ 871$ \\
\hline Labor Expense & $\$ 514$ & $\$ 493$ \\
\hline Total Capital Stock & $\$ 1,947$ & $\$ 1,339$ \\
\hline IT Capital Stock & $\$ 28.5$ & $\$ 22.4$ \\
\hline Total Employees & 13,681 & 13,066 \\
\hline & & $6.17 \%$ \\
\hline Pretax Return on Assets (1 Year) & $5.51 \%$ & $18.69 \%$ \\
\hline Total Shareholder Return (1 Year) & $17.24 \%$ & $11.15 \%$ \\
\hline Sales Growth (1 Year) & $8.99 \%$ & 399 \\
\hline
\end{tabular}

Note: Dollar figures are in millions.

Sample limited to firms with a complete set of production inputs (capital, labor, value-added, IT). 


\section{References}

Aguirregabiria, Victor, Cesar Alonso-Borrego, "Employment Occupational Structure, Technological Capital and Reorganization of Production," University of Chicago Working Paper, 2000.

Applegate, Linda M., James Cash, and D. Quinn Mills, "Information Technology and Tomorrow's Manager," Harvard Business Review, November-December, (1988) 128-136.

Athey, Susan, and Scott Stern, "An Empirical Framework for Testing Theories about Complementarities in Organizational Design," NBER Working Paper No. 6600, 1998.

Attewell, Paul, and James Rule, "Computing and Organizations: What We Know and What We Don't Know," Communications of the ACM, (1984), 27 pp. 1184-1192.

Autor, David, Lawrence Katz, and Alan Krueger, (1998), "Computing Inequality: Have Computers Changed the Labor Market?” Quarterly Journal of Economics, November (XIII 1998), 1169-1214.

Autor, David, Frank Levy, and Richard Murnane, "Upstairs, Downstairs: Computer-Skill Complementarity and Computer-Labor Substitution on Two Floors of a Large Bank,” NBER Working Paper No. 7890, 2000.

Baker George, and Thomas Hubbard, "Contractibility and Asset Ownership: On-Board Computers and Governance in U.S. Trucking," mimeo, (University of Chicago Business School, 1999).

Barras, R., "Interactive Innovation in Financial and Business Services: The Vanguard of the Service Revolution," Research Policy, (1990), No. 19.

Bartel, Anne and Frank Lichtenberg, "The Comparative Advantage of Educated Workers in Implementing New Technology," Review of Economics and Statistics, (LXIV 1987), 1-11.

Berman, Eli, John Bound and Zvi Griliches, "Changes in the Demand for Skilled Labor within U.S. Manufacturing Industries," Quarterly Journal of Economics, (1994), 109, 367-98.

Berndt, Ernst, Catherine J. Morrison, and Larry S. Rosenblum, "High-Tech Capital, Economic Performance and Labor Composition in U.S. Manufacturing Industries: An Exploratory Analysis," (MIT Working Paper, 1992).

Black, Sandra, and Lisa Lynch, "How to Compete: The Impact of Workplace Practices and Information

Technology on Productivity," Review of Economics and Statistics, (1997) forthcoming.

Bound, John and George Johnson, "Changes in the Structure of Wages in the 1980s: An Evaluation of Alternative Explanations," American Economic Review, (1992), 82,3: 371-392.

Bresnahan, Timothy, "Computerization and Wage Dispersion: An Analytic Reinterpretation," Economic Journal, (1999), Vol. 109, No. 7, pp 390-415.

Bresnahan, Timothy, "The Changing Structure of Innovation in the Computer Industry," in D. Mowery et al., editors, U.S. Industry in 2000: Studies in Competitive Performance, (National Academy Press, Washington, 2000).

Bresnahan, Timothy, Erik Brynjolfsson, Lorin Hitt, "Information Technology and Recent Changes in Work Organization Increase the Demand for Skilled Labor," in M. Blair and T. Kochan, Eds., The New Relationship: Human Capital in the American Corporation, (1999) Washington, DC: Brookings.

Bresnahan, Timothy, and Shane Greenstein, "Technical progress and co-invention in computing and in the uses of computers," Brookings Papers on Economic Activity, Micro, (1997) pp. 1-83.

Brynjolfsson, Erik and Lorin Hitt, "Information Technology as a Factor of Production: The Role of Differences Among Firms," Economics of Innovation and New Technology. (1995), 3 (4): 183-200.

Brynjolfsson, Erik and Lorin Hitt, "Paradox Lost? Firm-level Evidence on the Returns to Information Systems Spending," Management Science, (1996), Vol. 42, No. 4, pp 541-558.

Brynjolfsson, Erik and Lorin Hitt, "Information Technology and Organizational Design: Evidence from Microdata," (MIT Sloan School Working Paper, 1997). 
Brynjolfsson, Erik, and Lorin Hitt, "Beyond Computation: Information Technology, Organization Transformation and Business Performance," Journal of Economic Perspectives, (2000).

Brynjolfsson, Erik and Haim Mendelson, "Information Systems and the Organization of Modern Enterprise," Journal of Organizational Computing, (1993), Vol. 3, No. 3, pp. 245-255.

Brynjolfsson, Erik and Shinkyu Yang, "The Intangible Costs and Benefits of Computer Investments: Evidence from Financial Markets," Proceedings of the International Conference on Information Systems, (1997).

Brynjolfsson, Erik, Amy Renshaw and Marshall Van Alstyne, "The Matrix of Change," Vol. 28, No. 2, pp. 37-54, Sloan Management Review, (1997).

Card, David and Thomas Lemieux, "Can Falling Supply Explain the Rising Return to College for Younger Men? A Cohort-Based Analysis," Quarterly Journal of Economics, CXVI, (2001).

Chennells, Lisa, John Van Reenen, "Establishment Level Earnings, Technology and the Growth of Inequality: Evidence from Britain," Economics of Innovation \& New Technology, (1998), Vol. 5(2-4): 139-64.

Council of Economic Advisors, Ed., Economic Report of the President. (Washington, D.C., US Government Printing Office, 1996).

Crowston, Kevin, and Thomas Malone, "Information Technology and Work Organization," Chapter 49 in: M. Helander, ed., Handbook of Human-Computer Interactions, (Elsevier Science, Amsterdam, 1988), pp. 1051-1070.

Davenport, Thomas, and James Short, "The New Industrial Engineering: Information Technology and Business Process Redesign,” Sloan Management Review (1990) 31.4: 11-27.

Davenport, Thomas, Process Innovation, (Cambridge, MA: Harvard Business School Press, 1994)

David, Paul. "The Dynamo and the Computer: An Historical Perspective on the Modern Productivity Paradox, "The American Economic Review, (1990), Vol. 80, No. 2, pp. 355-361.

DiNardo, John, and Jorn-Steffen Pischke, "The Returns to Computer Use Revisited: Have Pencils Changed the Wage Structure Too?” Quarterly Journal of Economics, (1997), 112 pp. 291-303.

Doms, Mark, Tim Dunne, Kevin Troske, “Workers, Wages, and Technology," Quarterly Journal of Economics, (1997), Vol. 112 (1) pp. 253-290.

Duguet, E. And Greenan, N., "La bias technologique: Une analyse econometrique sur donnees individuelles," Revue Economique (1997), 48 (5): 1061-89.

Dunne, Tim, John Haltiwanger, and Kevin Troske, "Technology and Jobs: Secular Changes and Cyclical Dynamics," Carnegie-Rochester Conference Series on Public Policy, (1997), Vol. 46 pp. 107-78.

Gill, Grandon, “Early Expert Systems: Where Are They Now?” MIS Quarterly, (1995), 19(1):51-82

Goldin, Claudia, and Lawrence Katz, "The Origins of Technology-Skill Complementarity,” Quarterly Journal of Economics, (1998), 113 pp. 693-732,

Goldin, Claudia, and Lawrence Katz, "The Returns to Skill in the United States Across the Twentieth Century" NBER Working Paper No.7126, 1999.

Gordon, Robert, "Measurement of Durable Goods Prices," (Chicago: University of Chicago Press (for NBER), 1990).

Hall, Bronwyn, "The Manufacturing Sector Master File: 1959-1987," NBER Working Paper Mo. 3366, 1990.

Hammer, Michael, "Reengineering Work: Don't Automate, Obliterate," Harvard Business Review, July-August, (1990), pp. 104-112.

Hitt, Lorin and Erik Brynjolfsson "Information Technology and Internal Firm Organization: An Exploratory Analysis" J. Management Information Systems, (1997), Vol. 14, No. 2, pp. 77-99.

Holmstrom, Bengt, and Paul Milgrom, "The Firm as an Incentive System," American Economic Review, (1994), 84 pp. 972-991.

Huselid, Mark, "The Impact of Human Resource Management Practices on Turnover, Productivity, and Corporate Financial Performance," Academy of Management Journal, (1994). 
Ichniowski, Casey, Thomas Kochan, David Levine, C. Olson and G. Strauss, "What works at work: Overview and Assessment", Industrial Relations, (1996), Vol. 35, No. 3 pp. 299-333.

Ichniowski, Casey, Katherine Shaw and Giovanna Prennushi, "The Effects of Human Resource Management Practices on Productivity," American Economic Review, (1997), pp. 291-313.

Ito, Harumi, "Essays on Investment Adjustment Costs", (Ph.D. Dissertation, Stanford University, 1996).

Jensen, Michael, "The Modern Industrial Revolution, Exit, and the Failure of Internal Control Systems," Journal of Finance, (1993), Vol. 48, No. 3, pp. 831-880.

Johnson, G., "Changes in Earnings Inequality: The Role of Demand Shifts," Journal of Economic Perspectives, (1997), 11, 2 pp. 41-54.

Katz, Lawrence and Kevin Murphy, "Changes in Relative Wages, 1963-1987: Supply and Demand Factors," Quarterly Journal of Economics, (1992), 107 pp. 35-78.

Kemerer, Chris, and Glenn L. Sosa, "Systems Development Risks in Strategic Information Systems," Information and Software Technology, (1991), 33(3) pp. 212-223.

Krueger, Alan, "How Computers Have Changed the Wage Structure? Evidence from Micro Data," Quarterly Journal of Economics, (1993), pp.33-60.

Lazear, Edward, "Personnel Economics", (Cambridge, MA: MIT Press, 1995).

Leavitt, H. J. and T. L. Whisler, "Management in the 1980s," Harvard Business Review, November-December, (1958).

Levy, Frank, Anne Beamish, Richard Murnane, and David Autor, "Computerization and Skills: Examples from a Car Dealership," (Mimeo, MIT, 1999).

Lucas, R., "Information Technology for Managers" (6 ${ }^{\text {th }}$ Edition). New York: McGraw-Hill, (1996).

Mairesse, Jacques and Nathalie Greenan "Using Employee Level Data in a Firm Level Econometric Study," NBER Working Paper No. W7028, 1999.

Malone, Thomas and Jack Rockart, “Computers, Networks and the Corporation,” Scientific American, (1991), Vol. 265(3) pp. 128-136.

Milgrom, Paul and John Roberts, “The Economics of Modern Manufacturing: Technology, Strategy, and Organization," American Economic Review, (1990), 80(3) pp. 511-528.

Osterman, Paul, "How Common is Workplace Transformation and Who Adopts It?” Industrial and Labor Relations Review, (1994), 47(2) pp. 173-188.

Radner, Roy, "The Organization of Decentralized Information Processing," Econometrica, (1993) 62 pp. 1109-1146.

Scott Morton, Michael, "The Corporation of the 1990s: Information Technology and Organizational Transformation," (Oxford University Press, 1991).

Wolff, Edward, "The Growth of Information Workers in the U.S. Economy, 1950-1990: The Role of Technological Change, Computerization, and Structural Change," The C.V. Starr Center for Applied Economics, New York University, 1996.

Zuboff, Shoshana, In the Age of the Smart Machine: The Future of Work and Power, New York: Basic Books, (1988). 
Table I: Organizational Practice and Human Capital Survey Variables

\begin{tabular}{|c|c|c|c|c|c|}
\hline & Range & Variable & $\mathrm{N}$ & Mean & Std. Dev. \\
\hline \multicolumn{6}{|l|}{ Variables Measuring Organization } \\
\hline \multicolumn{6}{|l|}{ Team-Based Work Organization } \\
\hline Use of Self-Managing Teams & $1-5$ & SMTEAM & 345 & 2.11 & 1.13 \\
\hline Use of Employee Involvement Groups & $1-5$ & QUALCIR & 345 & 2.85 & 1.21 \\
\hline Use of Team Building Activities & $1-5$ & $T E A M B L D$ & 345 & 2.95 & 1.17 \\
\hline Promote for Teamwork & $1-5$ & PROMTEAM & 345 & 3.59 & 0.95 \\
\hline Breadth of Jobs & $1-5$ & $B R O A D$ & 345 & 3.25 & 0.99 \\
\hline \multicolumn{6}{|l|}{ Individual Decision Authority } \\
\hline Who Decides Pace of Work ( $3=$ workers) & $1-3$ & $P A C E$ & 345 & 1.33 & 0.37 \\
\hline Who Decides Method of Work (same) & $1-3$ & METHOD & 345 & 1.39 & 0.38 \\
\hline \multicolumn{6}{|l|}{ Human Capital Measures (Levels) } \\
\hline \multicolumn{6}{|l|}{ Manager's Assessments 1-5 } \\
\hline Skill Level of Work & $1-5$ & SKILL & 345 & 3.60 & 0.86 \\
\hline Education Level & $1-5$ & $E D U C$ & 345 & 2.48 & 0.66 \\
\hline \multicolumn{6}{|l|}{ Education } \\
\hline Workers w/ High School or Less & $0-100 \%$ & $\% H S E D$ & 263 & $59.3 \%$ & $27.8 \%$ \\
\hline Workers with Some College & $0-85 \%$ & $\% S C E D$ & 263 & $23.3 \%$ & $17.5 \%$ \\
\hline Workers Completed College & $0-100 \%$ & $\% C O L L$ & 263 & $17.4 \%$ & $21.0 \%$ \\
\hline \multicolumn{6}{|l|}{ Occupation Mix } \\
\hline Unskilled Blue Collar (\%) & $0-95 \%$ & $\% U S$ & 337 & $18.4 \%$ & $21.4 \%$ \\
\hline Skilled Blue Collar (\%) & $0-85 \%$ & $\% S K$ & 337 & $24.7 \%$ & $21.1 \%$ \\
\hline Clerical $(\%)$ & $0-80 \%$ & $\% C L$ & 337 & $19.4 \%$ & $17.6 \%$ \\
\hline Professionals $(\%)$ & $0-90 \%$ & $\% P F$ & 337 & $20.7 \%$ & $16.8 \%$ \\
\hline Managers $(\%)$ & $0-50 \%$ & $\% M G$ & 337 & $16.8 \%$ & $8.5 \%$ \\
\hline \multicolumn{6}{|l|}{ Human Capital (Investment) } \\
\hline Pre-Employment Screen for Education & $1-5$ & SCNED & 345 & 3.31 & 0.89 \\
\hline Training (\% workers involved) & $0-100 \%$ & TRAIN & 345 & $48.0 \%$ & $36.1 \%$ \\
\hline Cross-train Workers & $1-5$ & XTRAIN & 345 & 3.16 & 0.98 \\
\hline
\end{tabular}

Source: Authors' Survey. 
Table II: IT Variables

\begin{tabular}{|lcccc|}
\hline & Variable & $\mathrm{N}$ & Mean & Std. Dev. \\
\hline CII Survey $^{*}$ & & & & \\
\hline Log(IT Capital) & LITCAP & 333 & 3.07 & 1.66 \\
\hline Total MIPS (Millions of instructions/sec.) & MIPS & 333 & 2,624 & 8,737 \\
\hline Total PCs & TOTPC & 333 & 4,560 & 10,997 \\
\hline & & & & \\
\hline Organizational Survey $^{* *}$ & & & & \\
\hline Degree of Computerization of Work 1-5 & COMP & 343 & 3.28 & 1.11 \\
\hline$\%$ Workers using General Purp. Computers & $\% G P$ & 290 & $53.0 \%$ & $33.8 \%$ \\
\hline$\%$ Workers using E-mail & $\% E M A I L$ & 290 & $31.0 \%$ & $32.2 \%$ \\
\hline
\end{tabular}

Source: "CII, ${ }^{* *}$ Authors' Survey.

Table III: Production function variables

\begin{tabular}{|c|c|c|c|c|}
\hline & Variable & $\mathrm{N}$ & Mean & Std. Dev. \\
\hline \multicolumn{5}{|l|}{$\begin{array}{l}\text { Compustat Variables } \\
1994 \text { Cross Section }\end{array}$} \\
\hline $\log ($ Sales $)$ & LSALES & 311 & 7.72 & 1.00 \\
\hline $\log ($ Value Added $)$ & $L V A$ & 311 & 6.79 & 1.02 \\
\hline $\log ($ Labor Expense $)$ & $L L A B O R$ & 311 & 6.17 & 1.09 \\
\hline $\log ($ Non-IT Capital) & LNITCAP & 311 & 7.43 & 1.44 \\
\hline $\log ($ Employment $)$ & LEMPLOY & 311 & 2.55 & 1.09 \\
\hline $\log ($ IT Capital $)$ & LITCAP & 311 & 2.60 & 1.49 \\
\hline \multicolumn{5}{|l|}{$\begin{array}{l}\text { Production Function Controls } \\
\text { Production Worker Composition }\end{array}$} \\
\hline Blue Collar (fraction of jobs listed) & $P R B L$ & 345 & $61.9 \%$ & $46.2 \%$ \\
\hline Clerical (fraction of jobs listed) & $P R C L$ & 345 & $31.4 \%$ & $43.4 \%$ \\
\hline Professional (fraction of jobs listed) & $P R P F$ & 345 & $4.6 \%$ & $17.5 \%$ \\
\hline
\end{tabular}

Source: "Compustat, " Authors' Survey.

Table IV: Correlations between Measures of IT, HK and Organization

\begin{tabular}{|c|c|c|c|c|c|}
\hline Measure & $\begin{array}{l}\text { Computer } \\
\text { Capital: } \\
\text { ITCAP }\end{array}$ & $\begin{array}{c}\text { Work } \\
\text { Organization: } \\
W O\end{array}$ & $\begin{array}{c}\text { Employee } \\
\text { Skill: } \\
\text { SKILL }\end{array}$ & $\begin{array}{c}\% \text { College } \\
\text { Educated: } \\
\% \text { COLL }\end{array}$ & $\begin{array}{c}\% \\
\text { Professionals: } \\
\% P F\end{array}$ \\
\hline Computer Capital (ITCAP) & 1 & & & & \\
\hline Work Organization $(W O)$ & $.18 * * *$ & 1 & & & \\
\hline Worker Skill $(S K I L L)$ & $.12 *$ & $.28 * * *$ & 1 & & \\
\hline Percent College $(\% C O L L)$ & .05 & $.34 * * *$ & $.17 * * *$ & 1 & \\
\hline Percent Professional $(\% P F)$ & $30 * * *$ & $.21 * * *$ & .06 & $.21 * * *$ & 1 \\
\hline
\end{tabular}

Spearman partial rank order correlations controlling for industry (9 sector dummy variables), employment (EMPLOY) and production worker composition (PRBL, PRCL). N=251-401, due to non-response and some measures limited to second and third wave surveys.

Key: $*-\mathrm{p}<.1, * *-\mathrm{p}<.05, * * *-\mathrm{p}<.01$; test is against the null hypothesis that the correlation is zero. 
Table V: Correlations between IT and Human Capital

\begin{tabular}{|c|c|c|c|c|c|c|}
\hline $\begin{array}{l}\text { Measure } \\
\text { (scale in parenthesis) }\end{array}$ & $\begin{array}{c}\% \text { Use Gen. } \\
\text { Purpose } \\
\text { Computing: } \\
\% G P\end{array}$ & $\begin{array}{l}\% \text { Use } \\
\text { e-mail: } \\
\% E M A I L\end{array}$ & $\begin{array}{l}\text { Computer- } \\
\text { ization of } \\
\text { work: } \\
\text { COMP }\end{array}$ & $\begin{array}{l}\text { Computer } \\
\text { Capital: } \\
\text { ITCAP }\end{array}$ & $\begin{array}{l}\text { Processing } \\
\text { Power: } \\
\text { MIPS }\end{array}$ & $\begin{array}{l}\text { Number of } \\
\text { PCs: } \\
\text { TOTPC }\end{array}$ \\
\hline \multicolumn{7}{|l|}{ Skills/Education $(\mathrm{N}=371)$} \\
\hline Skill Levels $(S K I L L)$ & $.20 * * *$ & $.29 * * *$ & $.36 * * *$ & .09 & $.15 * * *$ & $.13 * *$ \\
\hline Education $(E D U C)$ & $.15 * *$ & $.26 * * *$ & $.24 * * *$ & .13 & .08 & .01 \\
\hline \multicolumn{7}{|l|}{ Education Distribution $(\mathrm{N}=237)$} \\
\hline High School Education (\%HSED) & $-.28 * * *$ & $-.37 * * *$ & $-.32 * * *$ & $-.11 *$ & $-.18 * * *$ & $-.15 * *$ \\
\hline College Graduate (\%COLL) & $.27 * * *$ & $.36 * * *$ & $.28 * * *$ & .07 & .14 & .05 \\
\hline \multicolumn{7}{|l|}{ Workforce Composition $(\mathrm{N}=303)$} \\
\hline Clerical $(\% C L)$ & -.02 & .04 & -.05 & -.08 & -.01 & -.03 \\
\hline Unskilled Blue Collar (\%US) & $-.22 * * *$ & $-.25 * * *$ & $-.17 * * *$ & -.08 & $-.13 * *$ & -.09 \\
\hline Skilled Blue Collar $(\% S K)$ & -.05 & -.05 & .05 & .05 & .09 & .02 \\
\hline Managers $(\% M G)$ & $.16^{* *}$ & $.13 * *$ & $.11 *$ & $.17 * *$ & $.15^{* *}$ & .10 \\
\hline Professionals $(\% P F)$ & $.16^{* *}$ & $.27 * * *$ & $.18 * * *$ & $.29 * * *$ & $.39 * * *$ & $.28 * * *$ \\
\hline \multicolumn{7}{|l|}{ HK Investment Policies $(\mathrm{N}=370)$} \\
\hline Training $(T R A I N)$ & $.17 * * *$ & $.14 * *$ & $.20 * * *$ & $.14 * *$ & $.15 * * *$ & $.14 * *$ \\
\hline Screen for Education $(S C N E D)$ & $.11 *$ & $.15 * * *$ & $.28 * * *$ & $.16 * * *$ & $.18 * * *$ & $.21 * * *$ \\
\hline Cross-training of workers (XTRAIN) & $.18 * * *$ & .07 & .07 & .02 & .02 & .03 \\
\hline \multicolumn{7}{|l|}{$\begin{array}{l}\text { HK Investment Policies }(\mathrm{N}=370) \\
(\text { control for } S K I L L \text { and } E D U C)\end{array}$} \\
\hline Training $(T R A I N)$ & $.14 * *$ & $.10 *$ & $.19 * * *$ & $.15 * * *$ & $.14 * * *$ & $.14 * * *$ \\
\hline Screen for Education $(S C N E D)$ & .07 & .08 & $.15^{* *}$ & $.16^{* * *}$ & $.15^{* * *}$ & $.19 * * *$ \\
\hline Cross-training of workers (XTRAIN) & $.18 * * *$ & .07 & .03 & .01 & -.05 & .01 \\
\hline
\end{tabular}

Spearman partial rank order correlations controlling for industry (9 sector dummy variables), employment (EMPLOY) and production worker composition (PRBL, PRCL). N=240-372, due to non-response and some measures limited to second and third wave surveys.

Key: $\quad *-\mathrm{p}<.1, * *-\mathrm{p}<.05, * * *-\mathrm{p}<.01$; test is against the null hypothesis that the correlation is zero. 
Table VI: IT demand over 1987-1994 as a function of human capital and workplace organization at the end of the sample period

\begin{tabular}{|c|c|c|c|c|}
\hline Dependent Variable & $\begin{array}{c}\text { Computer } \\
\text { Capital: } \\
\log (I T C A P)\end{array}$ & $\begin{array}{c}\text { Computer } \\
\text { Capital: } \\
\log (I T C A P)\end{array}$ & $\begin{array}{c}\text { Computer } \\
\text { Capital: } \\
\log (I T C A P)\end{array}$ & $\begin{array}{l}\text { Ordinary } \\
\text { Capital: } \\
\log (\text { NITCAP })\end{array}$ \\
\hline Variable & & WO & $\begin{array}{l}\text { Education+ } \\
\text { WO }\end{array}$ & $\begin{array}{c}\text { Education+ } \\
W O\end{array}$ \\
\hline & Col (1) & Col (2) & Col ( 3) & Col (4) \\
\hline $\begin{array}{l}\text { Worker Skill } \\
\text { (SKILL) }\end{array}$ & $\begin{array}{l}.142 * * \\
(.0559)\end{array}$ & $\begin{array}{l}.0915 \\
(.0608)\end{array}$ & $\begin{array}{l}.0756 \\
(.0611)\end{array}$ & $\begin{array}{l}.0464 \\
(.0681)\end{array}$ \\
\hline $\begin{array}{l}\text { College Education } \\
(\% \text { COLL })\end{array}$ & & & $\begin{array}{l}.0108^{*} \\
(.0600) \\
\end{array}$ & $\begin{array}{l}-.0745 \\
(.0711) \\
\end{array}$ \\
\hline $\begin{array}{l}\text { Some College } \\
(\% S C E D)\end{array}$ & & & $\begin{array}{l}-.0174 \\
(.0573)\end{array}$ & $\begin{array}{l}.0122 \\
(.0603)\end{array}$ \\
\hline $\begin{array}{l}\text { Decentralization } \\
(W O)\end{array}$ & & $\begin{array}{l}.142 * * \\
(.0642)\end{array}$ & $\begin{array}{l}.123^{*} \\
(.0641)\end{array}$ & $\begin{array}{c}.0116 \\
(.0641) \\
\end{array}$ \\
\hline $\begin{array}{l}\log (\text { Value-Added }) \\
\log (\text { VA })\end{array}$ & $\begin{array}{l}.714 * * * \\
(.115) \\
\end{array}$ & $\begin{array}{l}.709 * * * \\
(.115)\end{array}$ & $\begin{array}{l}.668 * * * \\
(.123) \\
\end{array}$ & $\begin{array}{l}.820 * * * \\
(.223)\end{array}$ \\
\hline $\begin{array}{l}\log (\text { Employment }) \\
\log (\text { Employ })\end{array}$ & $\begin{array}{l}.104 \\
(.128) \\
\end{array}$ & $\begin{array}{l}.0857 \\
(.130) \\
\end{array}$ & $\begin{array}{l}.128 \\
(.131) \\
\end{array}$ & $\begin{array}{l}.0486 \\
(.214) \\
\end{array}$ \\
\hline $\begin{array}{l}\text { Controls: Sector } \\
\text { Dummies, Year } \\
\text { Dummies, Workforce } \\
\text { Composition }(P R C L, \\
P R P F)\end{array}$ & Controls & Controls & Controls & Controls \\
\hline $\mathrm{R}^{2}$ & $49.3 \%$ & $50.2 \%$ & $50.6 \%$ & $62.3 \%$ \\
\hline $\mathrm{N}$ & 1331 & 1331 & 1331 & 1331 \\
\hline
\end{tabular}

Key: $\quad *-\mathrm{p}<.1, * *-\mathrm{p}<.05, * * *-\mathrm{p}<.01$

Huber-white robust (clustered by firm) standard errors utilized to account for repeated observations for same firm. Largest common sample used - results similar in maximal sample for each regression (not shown). 
Table VII: Relationship between human capital investment and various measures of information technology, with controls for skill and workplace organization

\begin{tabular}{|c|c|c|c|c|c|c|}
\hline Dependent Variable & $\begin{array}{c}\text { Human } \\
\text { Capital } \\
\text { Investment }\end{array}$ & $\begin{array}{c}\text { Human } \\
\text { Capital } \\
\text { Investment }\end{array}$ & $\begin{array}{c}\text { Human } \\
\text { Capital } \\
\text { Investment }\end{array}$ & $\begin{array}{c}\text { Human } \\
\text { Capital } \\
\text { Investment }\end{array}$ & $\begin{array}{c}\text { Human } \\
\text { Capital } \\
\text { Investment }\end{array}$ & $\begin{array}{c}\text { Human } \\
\text { Capital } \\
\text { Investment }\end{array}$ \\
\hline \multicolumn{7}{|l|}{ Variable } \\
\hline & $\operatorname{Col}(1)$ & $\operatorname{Col}(2)$ & $\operatorname{Col}(3)$ & $\operatorname{Col}(4)$ & $\operatorname{Col}(5)$ & $\operatorname{Col}(6)$ \\
\hline $\begin{array}{l}\text { Computerization } \\
\log (I T C A P / E M P L O Y)_{-4}\end{array}$ & $\begin{array}{l}.180 * * * \\
(.0673)\end{array}$ & $\begin{array}{l}.154 * * * \\
(.0614)\end{array}$ & & & & \\
\hline $\begin{array}{l}\text { Computerization } \\
\log (I T C A P / E M P L O Y)\end{array}$ & & & $\begin{array}{l}.184 * * \\
(.0735)\end{array}$ & & & \\
\hline $\begin{array}{l}\text { Computerization } \\
(\mathrm{COMP})\end{array}$ & & & & $\begin{array}{l}.994 * \\
(.522) \\
\end{array}$ & & \\
\hline $\begin{array}{l}\text { Computerization } \\
\log (\mathrm{MIPS} / E M P L O Y)_{-4}\end{array}$ & & & & & $\begin{array}{l}.172 * * * \\
(.0644)\end{array}$ & \\
\hline $\begin{array}{l}\text { Computerization } \\
\log (\text { TOTPC/ } E M P L O Y)_{-4}\end{array}$ & & & & & & $\begin{array}{c}.0812 \\
(.0650) \\
\end{array}$ \\
\hline $\begin{array}{l}\text { Work Organization } \\
(W O)\end{array}$ & & $\begin{array}{l}.419 * * * \\
(.0589)\end{array}$ & $\begin{array}{l}.409 * * * \\
(.0594)\end{array}$ & $\begin{array}{l}.314 * * * \\
(.0982)\end{array}$ & $\begin{array}{l}.403 * * * \\
(.0607)\end{array}$ & $\begin{array}{l}.449 * * * \\
(.0569)\end{array}$ \\
\hline $\begin{array}{l}\text { Skills } \\
(S K I L L)\end{array}$ & $\begin{array}{l}.237 * * * \\
(.0629) \\
\end{array}$ & $\begin{array}{l}.0948 \\
(.0607) \\
\end{array}$ & $\begin{array}{l}.0930 \\
(.0609) \\
\end{array}$ & $\begin{array}{l}-.240 \\
(.200) \\
\end{array}$ & $\begin{array}{c}.0911 \\
(.0618) \\
\end{array}$ & $\begin{array}{c}.100 \\
(.0626) \\
\end{array}$ \\
\hline Industry Controls & $\begin{array}{l}\text { Sector } \\
\text { Dummies }\end{array}$ & $\begin{array}{l}\text { Sector } \\
\text { Dummies }\end{array}$ & $\begin{array}{l}\text { Sector } \\
\text { Dummies }\end{array}$ & $\begin{array}{l}\text { Sector } \\
\text { Dummies }\end{array}$ & $\begin{array}{l}\text { Sector } \\
\text { Dummies }\end{array}$ & $\begin{array}{l}\text { Sector } \\
\text { Dummies }\end{array}$ \\
\hline $\mathrm{N}$ & 250 & 250 & 250 & 250 & 250 & 250 \\
\hline
\end{tabular}

Key: $\quad *-\mathrm{p}<.1, * *-\mathrm{p}<.05, * * *-\mathrm{p}<.01$

All variables standardized to mean 0 , unit variance.

IV: Computerization (ITCAP/EMPLOY and COMP) instrumented with 4th lagged $\log (I T C A P / E M P L O Y)$; all other variables considered exogenous. 
Table VIII: Productivity effects of computer-human capital and computer-work organization-human capital interactions from 1987-1994 using human capital and workplace organization metrics at the end of the sample

\begin{tabular}{|c|c|c|c|c|c|}
\hline Dependent Variable & $\log (\mathrm{VA})$ & $\log (\mathrm{VA})$ & $\log (\mathrm{VA})$ & $\log (\mathrm{VA})$ & $\log (\mathrm{VA})$ \\
\hline $\begin{array}{l}\text { Specification } \\
\text { Jariable }\end{array}$ & Baseline & $\begin{array}{l}\text { Baseline+ } \\
\text { Skills }\end{array}$ & $\begin{array}{c}\text { Baseline + } \\
\text { Skills } \\
\text { (maximum } \\
\text { sample) }\end{array}$ & $\begin{array}{l}\text { Baseline+ } \\
\text { Org } \\
\text { (maximum } \\
\text { sample) }\end{array}$ & $\begin{array}{c}\text { Baseline+ } \\
\text { College }\end{array}$ \\
\hline & $\operatorname{Col}(1)$ & $\operatorname{Col}(2)$ & $\operatorname{Col}(3)$ & $\operatorname{Col}(4)$ & $\operatorname{Col}(5)$ \\
\hline $\begin{array}{l}\text { IT Stock } \\
(\log (I T C A P))\end{array}$ & $\begin{array}{c}.0347 * * \\
(.0175) \\
\end{array}$ & $\begin{array}{r}.0330 * * \\
(.0166) \\
\end{array}$ & $\begin{array}{c}.0371 * * * \\
(.0148) \\
\end{array}$ & $\begin{array}{l}.0358 * \\
(.0147) \\
\end{array}$ & $\begin{array}{l}.0353^{*} \\
(.0181) \\
\end{array}$ \\
\hline $\begin{array}{l}\text { Capital Stock } \\
(\log (N I T C A P))\end{array}$ & $\begin{array}{l}.138 * * * \\
(.0298)\end{array}$ & $\begin{array}{l}.140 * * * \\
(.0295)\end{array}$ & $\begin{array}{l}.157 * * * \\
(.0247) \\
\end{array}$ & $\begin{array}{l}.154 * * * \\
(.0246)\end{array}$ & $\begin{array}{l}.144 * * * \\
(.0293)\end{array}$ \\
\hline $\begin{array}{l}\text { Labor Input } \\
(\log (L A B O R)) \\
\end{array}$ & $\begin{array}{l}.753 * * \\
(.0422) \\
\end{array}$ & $\begin{array}{l}.753 * * * \\
(.0416) \\
\end{array}$ & $\begin{array}{l}.752 * * * \\
(.0373) \\
\end{array}$ & $\begin{array}{l}.748 * * * \\
(.0374) \\
\end{array}$ & $\begin{array}{l}.743 * * * \\
(.0407) \\
\end{array}$ \\
\hline $\begin{array}{l}\text { Worker Skill } \\
(\text { SKILL })\end{array}$ & & $\begin{array}{l}.00167 \\
(.0210) \\
\end{array}$ & $\begin{array}{l}.00244 \\
(.0155) \\
\end{array}$ & & \\
\hline $\begin{array}{l}\text { College Education } \\
(\% C O L L)\end{array}$ & & & & & $\begin{array}{l}-.00795 \\
(.0244) \\
\end{array}$ \\
\hline $\begin{array}{l}\text { IT x Skill } \\
(\log (I T C A P) \times S K I L L)\end{array}$ & & $\begin{array}{c}.0262 \\
(.0195) \\
\end{array}$ & $\begin{array}{l}.0224^{*} \\
(.0155) \\
\end{array}$ & & \\
\hline $\begin{array}{l}\text { IT x College } \\
(\log (I T C A P) \times \% C O L L)\end{array}$ & & & & & $\begin{array}{c}.0550 * * \\
(.0272) \\
\end{array}$ \\
\hline $\begin{array}{l}\text { Work Organization } \\
(W O)\end{array}$ & & & & $\begin{array}{l}.0218 * \\
(.0129)\end{array}$ & \\
\hline $\begin{array}{l}\text { Work Organization } \times \text { IT } \\
(W O \times \log (I T C A P))\end{array}$ & & & & $\begin{array}{c}.0162 * \\
(.00844) \\
\end{array}$ & \\
\hline Controls & $\begin{array}{c}\text { Sector } \\
\text { Dummies, } \\
\text { Year } \\
\text { Dummies } \\
\end{array}$ & $\begin{array}{c}\text { Sector } \\
\text { Dummies, } \\
\text { Year } \\
\text { Dummies } \\
\end{array}$ & $\begin{array}{c}\text { Sector } \\
\text { Dummies, } \\
\text { Year } \\
\text { Dummies } \\
\end{array}$ & $\begin{array}{c}\text { Sector } \\
\text { Dummies, } \\
\text { Year } \\
\text { Dummies } \\
\end{array}$ & $\begin{array}{c}\text { Sector } \\
\text { Dummies, } \\
\text { Year } \\
\text { Dummies } \\
\end{array}$ \\
\hline $\mathrm{N}$ & 1331 & 1331 & 2225 & 2225 & 1331 \\
\hline $\mathrm{R}^{2}$ & $90.8 \%$ & $90.9 \%$ & $92.9 \%$ & $92.8 \%$ & $91.2 \%$ \\
\hline
\end{tabular}

Key: $*-\mathrm{p}<.1, * *-\mathrm{p}<.05, * * *-\mathrm{p}<.01$; Huber-white robust (clustered by firm) standard errors utilized to account for repeated observations for same firm. Largest common sample used except for column 3 and 4 that utilizes the full sample - results similar in maximal sample for the other regressions (not shown). 
Table IX: Correlations between manager's perception of computer effects with computer use, Human Capital and Decentralization (1-5 scale with 3 = "no change")

\begin{tabular}{|c|c|c|c|c|}
\hline Measure & $\begin{array}{c}\text { Computers } \\
\text { increase } \\
\text { Skill }\end{array}$ & $\begin{array}{l}\text { Computers } \\
\text { increase } \\
\text { Autonomy }\end{array}$ & $\begin{array}{l}\text { Computers } \\
\text { increase } \\
\text { Monitoring }\end{array}$ & $\begin{array}{c}\text { Computers } \\
\text { routinize work }\end{array}$ \\
\hline & $(C S K I L L)$ & $\overline{(C F R E E D)}$ & $\begin{array}{l}\text { CMONIT1 + } \\
\text { CMONIT2 }) / 2\end{array}$ & $($ CROUT $)$ \\
\hline Mean & $4.17 * * *$ & $3.58 * * *$ & $3.59 * * *$ & 2.96 \\
\hline Computer Capital (ITCAP) & .09 & -.02 & -.06 & -.08 \\
\hline$\%$ Use Computer $(\% G P)$ & $.25 * * *$ & .07 & -.04 & .00 \\
\hline$\%$ Use e-mail (\%E-mail) & $.20 * * *$ & $.12 * *$ & -.04 & $-.10^{*}$ \\
\hline Work Organization $(W O)$ & $.19 * * *$ & $.13 * * *$ & .03 & .05 \\
\hline Worker Skill $(S K I L L)$ & $.27 * * *$ & $.20 * * *$ & $.12 * *$ & .04 \\
\hline Percent College $(\% C O L L)$ & $.19 * * *$ & .03 & -.07 & $-.12 *$ \\
\hline Human Capital Investment (HKINVEST) & $.22 * * *$ & $.10^{*}$ & -.01 & -.01 \\
\hline
\end{tabular}

Spearman partial rank order correlations controlling for industry ( 9 sector dummy variables), employment (EMPLOY) and production worker composition (PRBL, PRCL). N=238-295.

Key: $*-p<.1, * *-p<.05, * * *-p<.01$; test is against the null hypothesis that the correlation is zero (or in the case of variable means, that our survey respondents rated it as "no change") 
Figure 1: Innovations in work organization, information technology, and output constitute a complementary system. Declines in the price of IT lead to innovation and increased adoption of all three components.

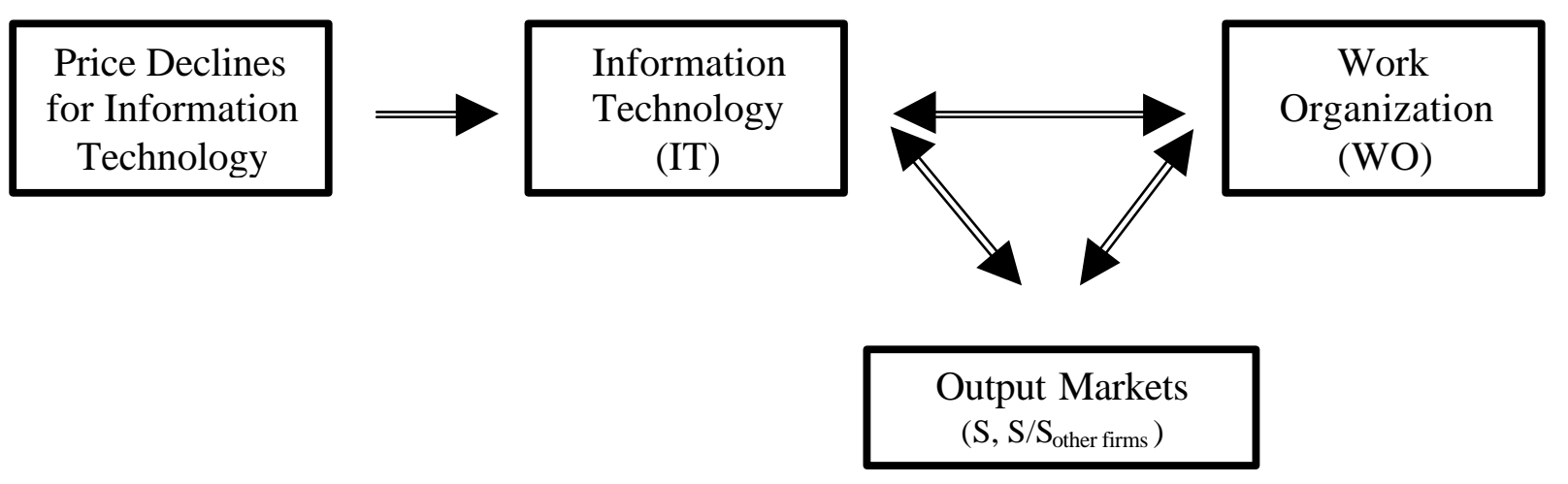

Figure 2: Innovations in work organization, information technology, and output constitute a complementary system. Adoption of this new system and its individual components affect the relative demand for skilled labor.

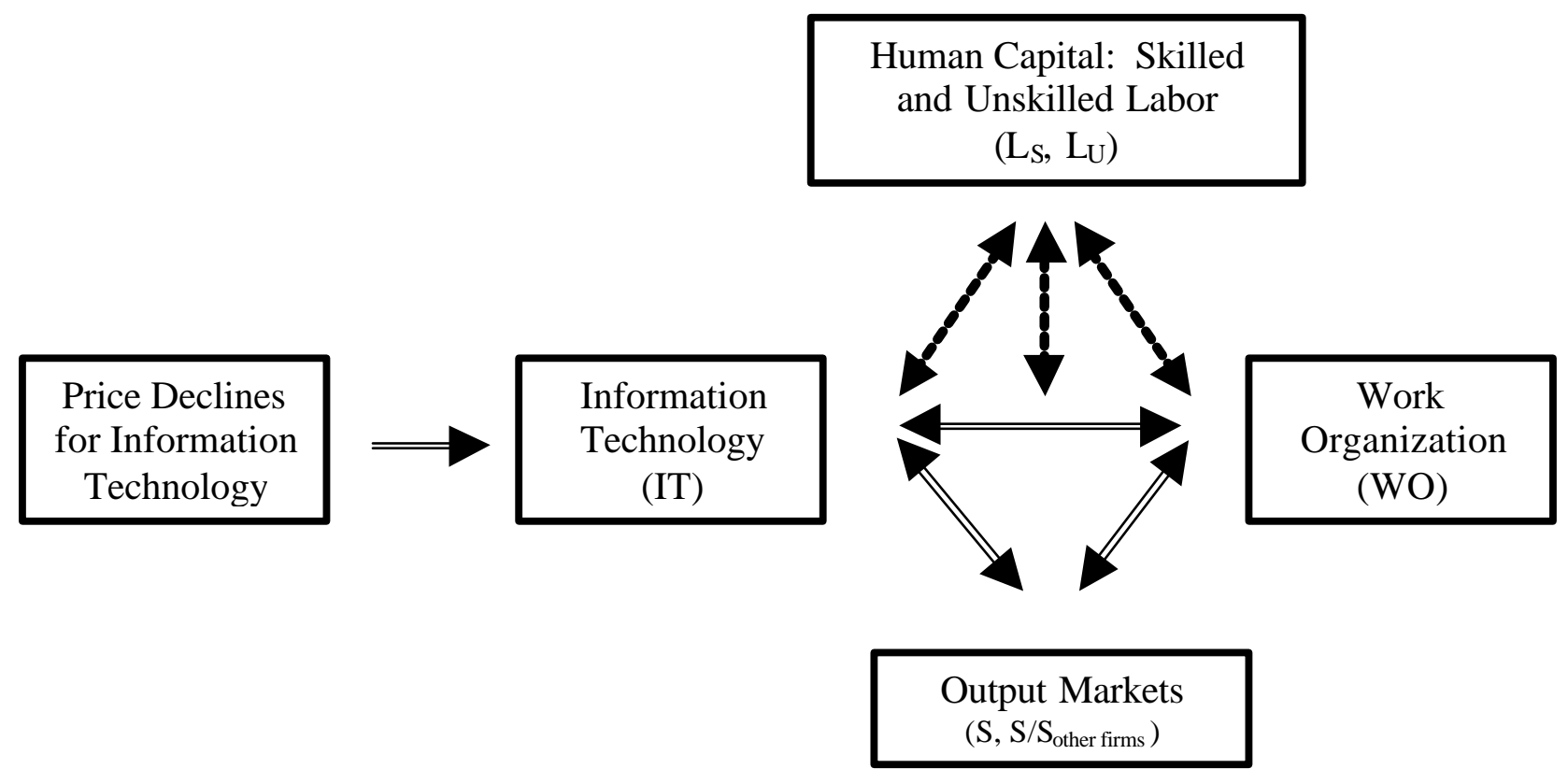




\section{$\underline{\text { Notes }}$}

1 There are a number of reviews of the growing empirical literature on wage inequality. See the symposium in the spring, 1997 issue of the Journal of Economic Perspectives, especially Johnson [1997]. Autor, Katz and Krueger [1998] provide a summary of this evidence, a bibliography, and an interesting supply-demand framework. See also Katz and Murphy [1992] and Bound and Johnson [1992] on the supply-demand distinction.

${ }^{2}$ See e.g. Krueger, [1993].

${ }^{3}$ Many of these studies treat broad firm-level measures of technological progress, with a variety of results. These include Doms et al. [1997] and Dunne et al. [1997] for the US, and Aguirregabiria and Alonso-Borrega [2000] for the United Kingdom and Dueget and Greenan [1997] and Mairesse and Greenan [1999] for France.

${ }^{4}$ The IT-intensive industries have seen the demand shift earlier [Wolff, 1996] and to a larger extent [Autor, Katz and Krueger, 1998; Berndt and Morrison, 1992] than other industries. Chennels and Van Reenen [1998] provide a very interesting discussion of a wide variety of empirical papers looking at all three levels of aggregation. .

5 See for example Applegate, Cash and Mills [1988], Attewell and Rule [1984], Barras [1990], Crowston and Malone [1988], Davenport and Short [1990], David [1990], Malone and Rockart [1991], Milgrom and Roberts [1990], Autor, Levy, and Murnane [1999], Scott Morton [1991], and Zuboff [1988].

6 See Ito [1996], Bresnahan and Greenstein [1997], and Brynjolfsson and Hitt [1997].

7 Systematic statistical work on shifts in computing architectures has found substantial adjustment costs [Ito, 1996; Bresnahan and Greenstein, 1997], and the case literature on IT implementation highlights difficulties in implementing concurrent organizational changes (e.g. Kemerer and Sosa, 1991 and Zuboff, 1988]. Moreover, there is additional evidence that monetary and non-monetary costs of these adjustments is larger than the capital investments in many cases [Brynjolfsson and Hitt, 1996; Brynjolfsson and Yang, 1997; Bresnahan, 2000].

8 For example, early attempts to implement expert systems in professional or technical environments (including equipment repair, automated computer code generation, and medical diagnoses) met with failure [Gill, 1995].

9 This might be thought of as an extreme version of Holmstrom and Milgrom's [1994] principles of job design.

${ }^{10}$ A more detailed description of our data set, and its relationship to earlier studies, and some related results can be found in Brynjolfsson and Hitt [1997] and Bresnahan, Brynjolfsson and Hitt [1999]. The survey instrument can be found at http://grace.wharton.upenn.edu/ 1hitt/.

${ }^{11}$ One potential difficulty of our sampling approach is that the practices reported by the respondent may not be representative of the work practices across the entire firm. To address this issue one wave of our survey asked about the uniformity of work practices: $65 \%$ said that all production workers have the same work practices and $82 \%$ reported that at least $80 \%$ of workers had the same work practices.

12 All the variables in $W O$ load positively in the first principal component of all six workplace organization variables in Table 1. Interestingly, Osterman [1994] reports that a similar set of team-oriented practices loaded on the first principal component in his survey of 694 establishments.

${ }^{13}$ The practices we use to define $W O$ are very similar to the "new work practices" that, according to Ichniowski et al. [1996], "have become increasingly common among U.S. businesses in recent years." In fact, 49.1\% of the establishments in Osterman's [1994] survey (see footnote 23) reported introducing "teams" in the five years prior to his survey year of 1992 . He also reports that $38 \%$ introduced job rotation practices, $71 \%$ TQM programs and $67.9 \%$ problem-solving groups in the years between 1987 and 1992; each of these also reflects increased decisionmaking by line workers. 
${ }^{14}$ This divides the economy into 4 manufacturing sectors (continuous process, high-tech, other durable, other nondurable), mining/construction, transport, utilities, finance, trade, and other services.

${ }^{15}$ Results from maximal samples, including as many as 2255 points for some analyses are available from the authors; they are consistent with this smaller sub-sample.

16 An alternative strategy would be to estimate the long-run system of factor demand equations with both c and c' endogenous. However, we do not observe prices for the factors varying across firms.

${ }^{17}$ DiNardo and Pischke [1997] make this argument and provide evidence that it is an important part of the correlation between individual worker wages and PC use observed by Krueger [1993].

${ }^{18}$ The respondents for the organizational practices survey were explicitly asked to consider a representative site for both the HK and IT questions. In contrast, the CII data were for the company as a whole.

${ }^{19}$ Four-year lags were chosen to be sufficiently long to examine long-term effects, but short enough to minimize data loss in our sample.

${ }^{20}$ Or it might simply reflect the fact that both COMP and HKINVEST were drawn from the same survey, improving the match of the unit of observation, while the instrument, lagged IT, comes from the CII data.

${ }^{21}$ See for instance Kemerer and Sosa [1991] for a catalog of disastrous IT projects, many representing substantial investments. Additional references to the difficulty of managing complex IT-enabled organizational change efforts appear in footnotes 6 and 7.

${ }^{22}$ Collinearity occasionally affects the estimates: worker skill and college education are not significant when included in the same regression with (unusually large) IT interaction terms, although they are significant when entered separately (not shown).

${ }^{23}$ One can, of course, construct a more intricate theory to explain the results. For instance, there could be correlated shocks to the productivities of firm-level factors could be confined to certain ranges of use of the factors in different ways in different firms. In empirical science, there is always an alternative explanation of this form; this one is distinctly pre-Copernican in structure.

${ }^{24}$ Discussions with executives at many of the firms in our present sample are an important part of the background to our interpretation of the econometric evidence. 